\title{
QUANTIFYING THE PERSONAL INCOME TAX BENEFITS OF BACKDATING: A CANADA - US COMPARISON
}

\author{
Ryan A. Compton* \\ Christopher C. Nicholls ${ }^{* *}$ \\ Daniel Sandler ${ }^{* * *}$ \\ Lindsay M. Tedds ${ }^{* * * *}$
}

\begin{abstract}
This paper contrasts the post-tax returns of backdated at-the-money options to currently-dated in-the-money options (with the same strike price as the backdated options) and demonstrates that a Canadian executive can earn a significantly larger after-tax return from backdated options compared to a US executive. We tie this to the favorable Canadian tax treatment of executive options relative to their treatment in the United States. The comparison suggests that the personal tax regime may have been one of the factors which impacted the desire to receive backdated options in lieu of other forms of compensation in Canada but not so in the United States.
\end{abstract}

* Associate Professor, Department of Economics, University of Manitoba, Winnipeg, Manitoba, Canada.compton@cc.umanitoba.ca

** Stephen Dattels Chair in Corporate Finance Law, Faculty of Law, Western University, London, Ontario, Canada. cnichol8@uwo.ca

*** Professor, Faculty of Law, Western University, London, Ontario, Canada, and Senior Research Fellow of the Tax Law and Policy Research Institute, Monash University, Melbourne, Australia. dsandler@uwo.ca

**** Assistant Professor, School of Public Administration, University of Victoria, Victoria, British Columbia, Canada. Itedds@uvic.ca

The authors would like to thank participants of the Deloitte Centre for Tax Education and Research, Tax Policy Research Symposium, Tax Expenditures and Public Policy in Comparative Perspective, and Shadow Economy, Tax Evasion, and Social Norms for helpful comments. The authors would also like to gratefully acknowledge the financial support from the Social Sciences and Humanities Research Council (Standard Research Grant \#410-2009-1955) and the research support of Chris Hannesson. 
I. INTRODUCTION 146

II. TAX POLICY AND THE DEMAND FOR BACKDATED OPTIONS ….............. 150

A. Canadian Personal Income Tax Rules for Executive Stock Options ..................151

B. US Tax Rules for Executive Stock Options.................................................... 152

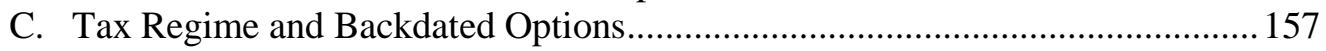

III. QUANTIFYING THE BENEFITS OF BACKDATING: EXAMPLES .................. 158

A. Example 1-Exercise and Sale on Same Date.................................................159

B. Example 2-Vest Over Five Years, Sale on Same Date as Exercise ................. 162

C. Example 3-Vest Over Five Years, Sale in Same Year as Exercise .................. 162

D. Example 4-Vest Over Five Years; Sale More Than One Year After Exercise 164

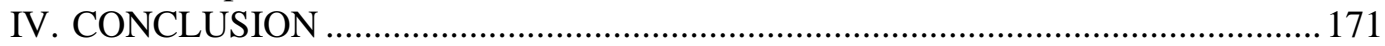

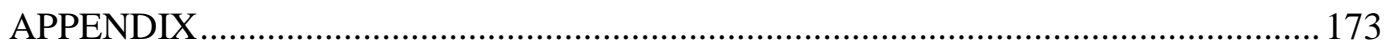




\section{INTRODUCTION}

The practice of backdating executive stock options has received significant attention in the U.S. financial ${ }^{1}$ and legal $^{2}$ literature, and has recently begun to be discussed in the Canadian legal literature. ${ }^{3}$ Backdating, in its most basic form, is the use of hindsight to selectively pick a local low point in a stock's trading price and issue executive stock options stipulating the selected date as the grant date when, in fact, the options are granted at a later date. Because the backdated options' strike price is lower than the market price on the actual grant date, the recipient has received something of greater monetary value (even if the options have not yet vested) than a correctly dated atthe-money option. ${ }^{4}$

Companies could reward executives with cash compensation or additional properly dated and priced incentive awards, including options, rather than engage in dubious backdating practices. ${ }^{5}$ It is clear that there must be reasons other than greed that have led so many to backdate executive options. ${ }^{6}$ Academics, regulators, and

${ }^{1}$ See generally Randall A. Heron \& Erik Lie, What Fraction of Stock Option Grants to Top Executives Have Been Backdated or Manipulated?, 55 MGMT. SCI. 513 (2009) (estimating "that 13.6\% of all option grants to top executives during the period 1996-2005 were backdated or otherwise manipulated."); Erik Lie, On the Timing of CEO Stock Option Awards, 51 MGMT. SCI. 802 (2005) (discussing how corporate executives are becoming more adroit at timing stock option awards to their advantage); M. P. Narayanan \& H. Nejat Seyhun, The Dating Game: Do Managers Designate Option Grant Dates to Increase Their Compensation?, 21 REV. FIN. STUD. 1907 (2008) (discussing the phenomenon of managers backdating or forward-dating stock options to maximize profitability depending on whether the stock price is rising or falling).

${ }^{2}$ See generally M. P. Narayanan, Cindy A. Schipani \& H. Nejat Seyhun, The Economic Impact of Backdating of Executive Stock Options, 105 Mich. L. REV. 1597 (2007) (discussing the value loss to shareholders of companies involved in backdating); David I. Walker, Unpacking Backdating: Economic Analysis and Observations on the Stock Option Scandal, 87 B.C. L. REV. 561 (2007) (discussing the economics of backdating and the attributes of companies under investigation).

${ }^{3}$ See generally Ryan A. Compton, Daniel Sandler \& Lindsay M. Tedds, Options Backdating: A Canadian Perspective, 47 CAN. BUS. L. J. 363 (2009) (analyzing the practice and prevalence of backdating in Canada and the legal, tax, and policy implications of the practice).

${ }^{4}$ The terms at-the-money, out-of-the-money, in-the-money, and not-in-the-money refer to when the exercise price of the option equals, exceeds, is below, and is at or above the market price of the underlying stock.

${ }^{5}$ See Compton et al., supra note 3, at 370-71 (discussing backdating in the U.S. and Canada in detail). In summary, backdating is permitted in the U.S. if no documents are falsified, shareholders are duly notified, the company's earnings and tax statements properly account for the backdating, and since 2004, both the individual and the company adhere to I.R.C. § 409A. See I.R.C. § 409A (2006). In reality, these conditions have seldom been met. In Canada, companies listed on the Toronto Stock Exchange (TSX) may not backdate at all, as the exchange requires all option awards of listed companies to be granted not-in-themoney. See infra note 9. Companies listed on the TSX Venture Exchange (TSX-V) may grant in-the-money options but may not backdate under any conditions.

${ }^{6}$ Similarly, the manipulation of stock options in the past may today encourage the use of a different incentive award, such as a restricted stock unit. A restricted stock unit is an unsecured promise to grant a set number of shares according to a vesting schedule, but only if forfeiture requirements, such as termination of employment or failing to meet performance goals, have not been triggered. See Mark P. Cussen, How Restricted Stock and RSUs are Taxed, INVESTOPEDIA (Feb. 10, 2012, 1:48 PM),

http://www.investopedia.com/articles/tax/09/restricted-stock-tax.asp (providing a more expansive definition). More research is required to identify whether other forms of incentive-based awards are indeed being manipulated. In addition, other pricing behavior may have supplanted backdating. For instance, Betty Wu finds that the incidence of option repricing has increased in the United States and that repricing seems to be associated with advantageous and temporary changes in a company's stock price. Betty Wu, Is CEO Stock Option Backdating or Otherwise Manipulation Another Form of Option Repricing?, 12 (Social Science 
practitioners alike have tried to gain a better understanding of these incentives and the roles they have played in the backdating scandal; however, there is as of yet no consensus regarding the causes of backdating. ${ }^{7}$ This is problematic because policy, legislative, or regulatory changes are unlikely to be effective if the root causes are unknown. Untangling the causes of backdating will remain elusive unless each factor is considered in detail using evidence from different regimes.

The first step in untangling the causes of backdating ${ }^{8}$ is to acknowledge that the backdating phenomenon must be driven by both supply and demand factors. From the supply side, the question is what motivates a firm to grant a backdated option, and from the demand side, what motivates an executive to demand (or, at the very least, accept) a backdated option? Both sets of motivations arise from the quantitative and qualitative benefits, costs, and risks of issuing and receiving backdated options. Most of the research to date has focused on supply side factors (e.g., accounting treatment, securities regulations, and corporate taxation), ${ }^{9}$ while there has been little discussion of demand

Research Network, Working Paper, 2012). Based on this evidence, Wu postulates that option repricing may have replaced backdating at some firms. See id. at 23.

${ }^{7}$ In addition, there is a paucity of empirical evidence about the incidence of backdating by Canadian firms. See infra note 21.

${ }^{8}$ Some observers, including the SEC, have concluded that backdating is a thing of the past due to increased corporate governance, higher perceived enforcement, and tightened reporting requirements. However, this conclusion appears to be premature since there is evidence which shows that backdating, while restricted, is still ongoing. In her empirical study, Wu demonstrates that option backdating is not associated with weak corporate governance, thereby questioning the influence of corporate governance provisions in the Sarbanes-Oxley Act of 2002 ("SOX") on backdating activities. Wu, supra note 6, at 5-6. Other scholars question the effectiveness of enforcement in curbing backdating since only about 140 companies in the United States are under federal investigation, yet empirical research indicates that the number of companies that have backdated options are in the thousands. See James Bickley \& Gary Shorter, Stock Options: The Backdating Issues, TAX NoTES TodAY, March 23, 2007, LEXIS 2007 TNT 57-17, at 16. In addition, Edelson and Whisenant review a sample of companies and suggest that, based on this sample, over 500 companies engaging in stock option award practices consistent with backdating remain undetected. Rick Edelson \& Scott Whisenant, A Study of Companies with Abnormally Favourable Patterns of Executive Stock Option Grant Timing 20 (Social Science Research Network, Working Paper, 2009). See infra note 65 for further discussion of enforcement. In the United States, the SEC reporting regulations were changed in 2002 to reduce the reporting period for stock option grants to two days. Sarbanes Oxley Act of 2002, Pub. L. No. 107-204, 116 Stat. 745, $\S 403,788-89$. Heron and Lie show that with the introduction of this new two-day reporting period, the return pattern associated with backdating is much weaker. Randall A. Heron \& Erik Lie, Does Backdating Explain the Stock Price Pattern Around Executive Stock Option Grants? 83 J. Fin. Econ. 271, 273 (2007). In a later study, Heron and Lie show the percentage of unscheduled grants backdated or manipulated fell dramatically following the introduction of the two-day rule. Heron \& Lie, supra note 1, at 514. Both studies note, however, that late filings continue to show a strong return pattern consistent with backdating, leading these authors to conclude that the efficacy of reporting requirements requires not only that grant award disclosures be filed on time but be filed at all. Heron \& Lie, supra note 8, at 294; Heron \& Lie, supra note 1, at 524. Despite simplified filing regimes, lax enforcement of the filing rules translates into a not insignificant number of insider reports being filed late or not at all. See Bickley \& Shorter supra, at 16; Lara E. Muller, Stock Option Backdating: Is the Government's Response Enough to Eliminate the Problem or Is It Still a Work in Progress? 51 SANTA ClaRA L. Rev. 331, 349-50 (2011).

${ }^{9}$ On the supply side, a frequently cited driver of both the use of stock options in compensation packages and backdating in the United States is the corporate tax treatment of non-qualified stock options ("NSOs"), which permits corporations to deduct NSOs for tax purposes. While on the surface this argument has some merit, particularly when considered within the framework of tax shelters (which, according to Michael Graetz, "are deals done by very smart people that, absent tax considerations, would be very stupid"), recent evidence suggests that the corporate tax treatment of NSOs was likely not a cause of backdating since options in general, and backdated options specifically, tend to be granted by companies with low profitability and little evidence of tax sheltering behavior. Michael J. Graetz, Tax Reform Unraveling, 21 J. ECON. PERSP. 
side factors. While understanding the propensity to backdate undoubtedly requires insight on the supply side factors to backdating (as it is the firms that ultimately grant executive stock options), without demand there would be no supply. Therefore understanding the drivers that influence demand is critical to understanding the whole story behind backdating of executive stock options.

The question of demand requires consideration of what an executive receives in monetary value from a backdated option (i.e., an option that appears to be an at-themoney option with an earlier grant date but is, in fact, in-the-money on the actual grant date) compared to a currently dated at-the-money option. There are two different points in time at which this value can be considered. The first point in time is the grant date. At that time, the Black-Scholes option pricing model $^{10}$ (or a variant of this model) could be used to estimate the monetary value that an executive actually receives when granted a backdated stock option. ${ }^{11}$ However, regardless of the Black-Scholes value of a backdated option (relative to an at-the-money option) at the time of receipt, what is ultimately of interest for executives is the benefit that backdating provides in monetary value, assuming they eventually exercise the options. We therefore focus on the value at exercise (and eventual sale of the shares) and demonstrate the role the income tax regime plays in determining the after-tax value to the executive.

This article considers in detail the potential role of personal income taxation in influencing demand for backdated options in Canada relative to the United States. Considering the role of the personal income tax treatment of executive options is important because taxes may influence the demand by executives for backdated options by altering the options' after-tax monetary value. ${ }^{12}$ In limiting the scope of this article in this way, we are not suggesting that taxation is the single most important factor in determining demand or that supply factors are not important. Instead, we are simply

69, 83 (2007); see also Jeri Seidman \& Bridget Stomberg, Stock-based Compensation and Tax Sheltering: Are They Negatively Related Due to Incentives of Tax Benefits? 4 (McCombs Research Paper Series, Working Paper No. ACC 03-11, 2011). Other supply factors also affect the ability of a corporation to grant in-the-money options that have the same before-tax value as backdated at-the-money options. For example, a company listed on the TSX cannot grant discounted stock options. TORONTO STOCK EXCHANGE Group InC., TSX COMPANY MANUAL $§ 613$ (2007). In contrast, U.S. stock exchanges permit in-the-money stock options provided that they are properly disclosed to shareholders, documents have not been falsified, and the options are reflected as such in the company's statement of earnings. See Compton et al., supra note 3, at 370 (discussing the differences between U.S. and Canadian stock exchange requirements, as well as relevant supply side factors that help explain the phenomenon in each country).

${ }^{10}$ Fischer Black \& Myron Scholes, The Pricing of Options and Corporate Liabilities, $81 \mathrm{~J}$. PoL. ECON. 637, 637-52 (1973). The Black-Scholes model is a generally accepted, albeit limited, method for calculating the theoretical value of an employee stock option. The basic intent of the model is to calculate the probability that an option will mature in-the-money (i.e., the value of the stock option today is the sum of all the probability-weighted payoffs at maturity, assuming that the asset returns follow a log normal distribution so that the sum of all the option payoffs at maturity multiplied by the probability of the occurrence of those payoffs is the value of the option today, ignoring discounting) by considering six variables: grant date; exercise price; option maturity; risk-free rate of interest for the option period; share's price volatility; and (if applicable) dividend yield. See id. The drawback of the Black-Scholes model is that it is based on the assumption that options can only be exercised at maturity (known as European-style options) and that the options are transferable. Other shortcomings include the fact that the interest rate and volatility are constrained as constants in the model and that the underlying stock is assumed to move according to a random walk.

${ }^{11}$ See Walker, supra note 2, at 581-82.

${ }^{12}$ See infra Appendix I (discussing a simple algebraic representation of the role that discounting and taxes play in determining the value of a stock option). 
advocating that a thorough explanation of the causes of backdating necessitates in-depth consideration of each relevant factor in turn and its potential contribution to backdating. ${ }^{13}$

We appreciate that income tax treatment is one piece of a larger puzzle that constitutes demand for backdated options by executives. Another piece is the insider reporting obligations imposed upon some executives by securities regulations. ${ }^{14}$ Given a lenient disclosure regime for reporting the grant and exercise of stock options, ${ }^{15}$ as some have argued currently exists in Canada, ${ }^{16}$ backdating could easily go undetected. Greed is often cited as the motive for backdated options. ${ }^{17}$ However, while greed could account for a desire for higher compensation, it cannot account for the form that such compensation takes. As executives could lawfully be paid equivalent amounts in cash (or properly dated options), it does not seem likely that greed is, at least by itself, a primary motivator for backdating. A better motivator may be the fact that backdated options are a form of what Bebchuk and Fried have called "stealth compensation." 18 Other considerations may affect backdating behavior, such as penalties and concomitant costs if the backdating is caught, ${ }^{19}$ including penalties arising from income tax reassessments and actions by securities regulators, as well as attorneys' fees, loss of employment, and potential loss of reputation. ${ }^{20}$

In order to assess the role of personal income taxation in backdating stock options, this study provides a comparative analysis of the personal income tax regime for executive stock options in Canada and the U.S. ${ }^{21}$ It is important to understand the

${ }^{13}$ Some argue that a multilateral approach is more appropriate when examining issues surrounding stock option backdating. See, e.g., Amin Mawani, Cancellation of Executive Stock Options: Tax and Accounting Income Considerations, 20 CONTEMP. ACCT. RES. 495, 499-500 (2003). But in order to be able to determine which factors need to be incorporated into the multilateral approach, a detailed unilateral approach is required. This is a common approach in the literature not only in this topic area, but most topic areas. That is, we take the approach of examining the role that personal income tax policy plays in determining the monetary value of a backdated stock option, ceteris paribus.

${ }^{14}$ See Bickley \& Shorter, supra note 8, at 11; Compton et al., supra note 8, at 474 .

${ }^{15}$ See Compton et al., supra note 8, at 489.

${ }^{16} \mathrm{Id}$.

${ }^{17}$ The former chair of the SEC, Arthur Levitt, has stated that backdating "represents the ultimate in greed." Charles Forelle \& James Bandler, Five More Companies Show Questionable Options Pattern, WALL ST. J., May 22, 2006; see also Geoffrey Manne \& Joshua D. Wright, Backdating Options and Why Executive Compensation Is Not All About Norms, 2 CoRP. GovernANCE L. Rev. 385, 392 (2006); Kristina Minnick \& Mengxin Zhao, Backdating and Director Incentives: Money or Reputation?, 32 J. FIN. RES. 449, 450-51 (2009).

${ }^{18}$ See Lucian A. Bebchuk \& Jesse M. Fried, Executive Compensation as an Agency Problem, $17 \mathrm{~J}$. ECON. PERSP. 71, 79 (2003) (defining stealth compensation as the practice of blurring or even concealing the total amount of compensation).

${ }^{19}$ See Compton, supra note 3, at 383-86.

${ }^{20}$ Nevertheless, some studies have found little evidence of reputational penalties resulting from backdating scandals. See Yonca Ertimur et al., Reputation Penalties for Poor Monitoring of Executive Pay: Evidence from Option Backdating, 104 J. FIN. ECON. 118, 119 (2012).

${ }^{21}$ The existing backdating literature focuses almost exclusively on the U.S. See Compton, supra note 3 , at 391 . We argue that a more complete understanding of the causes of backdating requires research that looks beyond the U.S. We believe that contrasting Canadian and U.S. regimes and evidence, at a minimum, can help elucidate the causes of backdating. In addition, such comparative work can also help uncover whether backdating activities are path-dependent and context specific, thereby providing policy lessons from and for other jurisdictions. For example, comparing and contrasting insider reporting obligations in a number of countries finds that placing the reporting onus on the corporation rather than the individual may have played a role in the lack of backdating in the U.K. and Australia. See Compton et al., supra note 8 , at 483,490 . Since current regulations and enforcement in the U.S. have failed to completely 
differences in these rules, particularly the extent to which these differences affect the after-tax return to a Canadian executive compared to a U.S. executive of backdated options. In the United States, the entire benefit realized by the employee at the time of exercise of most executive stock options is included in income, ${ }^{22}$ while in Canada, assuming certain conditions are met, the benefit is taxed at the same effective rate as capital gains (and thus is subject to a lower tax rate than if taxed as regular employment income). Part II considers these personal income tax rules in detail. In particular, the relevant personal income tax rules in the two countries are compared and contrasted to demonstrate the role these rules may play in determining the demand for backdated options in the two countries. ${ }^{23}$ As will be shown, this is potentially an important component in the decision of executives to accept backdated stock options and may provide an additional incentive for executives to demand them in Canada.

\section{TAX POLICY AND THE DEMAND FOR BACKDATED OPTIONS}

The taxation of stock options varies significantly between Canada and the United States. ${ }^{24}$ In this part we summarize the differences, focusing on backdated options and incorporating a discussion of recent U.S. changes regarding the taxation of discounted stock options enacted in 2004 on the heels of the Enron, WorldCom, and Tyco scandals.

eradicate the backdating problem, this suggests a continued lack of understanding of the drivers of the behavior and that further policy interventions are required. See id. at 489-90.

${ }^{22}$ This is because most executive stock options issued in the U.S. are NSOs. 1 EDwARD F. KOREN et al., Estate TaX \& Personal Financial Planning $§$ 2:68 (2012).

${ }^{23}$ While beyond the scope of this paper, we note a few things concerning the corporate taxation of executive stock options in the United States that have no counterpart in Canada. In particular, it has been suggested that corporate tax may increase the proclivity to backdate in the United States, but not in Canada, because U.S. corporations can deduct the value of most stock option benefits whereas Canadian corporations cannot. We disagree with this view. Subject to the possible application of $\S 162(\mathrm{~m})$ of the Internal Revenue Code ("I.R.C.") (which restricts a public corporation's ability to deduct more than $\$ 1$ million in compensation paid to the corporation's CEO and next four highest paid officers), U.S. corporations are entitled to a deduction for employee stock options only if the employee is required to report the stock option benefit as an income inclusion. See I.R.C. § 162(m) (West Supp. 2011). Not-in-the-money options are not subject to $\S 162(\mathrm{~m})$ whereas in-the-money options are. Thus, a corporation is generally entitled to a deduction for NSOs and Incentive Stock Options ("ISOs") where the shares are sold within one year after the options are exercised. NSOs may or may not be subject to the limitation in $\S 162(\mathrm{~m})$ depending on what makes them NSOs, while ISOs held less than one year would not be subject to $\S 162(\mathrm{~m})$ (because ISOs cannot be granted in-the-money). See id. However, regardless of how long the stock acquired pursuant to ISOs are actually held, it seems fair to assume that at the time of grant of the ISO, the employer could not expect a deduction, since no deduction is available if the ultimate share sale qualifies for ISO treatment. Therefore from the employer's perspective, there seems to be no preference accorded to backdated options that appear to be ISOs and currently dated options that are, in fact, ISOs. From the corporation's perspective, the backdating preference would appear to be limited to NSOs that are granted-or, more precisely, appear to be granted-not-in-the-money (i.e., stock options in excess of the $\$ 100,000$ per year threshold for ISOs). This is because the corporation is definitely entitled to deduct the value of such options when included in income by the employee without the potential application of $\S 162(\mathrm{~m})$. See I.R.C. $\S 422(\mathrm{~d})$ (2006). A second issue is that backdated options, assuming they are discovered, are necessarily NSOs and the employer would be entitled to a deduction, subject to the limitation in $§ 162(\mathrm{~m})$. See I.R.C. § 162(m) (West Supp. 2011). However, the deduction is only of value to the corporation if it is otherwise subject to tax (i.e., it is profitable). Nonetheless, many of the corporations that were cited for backdating in the United States were in the high-tech sector and may well not have been profitable. See Walker, supra note 2, at 566. In sum, it is our view that corporate taxation would have had little impact on the propensity to backdate in the United States.

${ }^{24}$ See generally Daniel Sandler, The Tax Treatment of Employee Stock Options: Generous to a Fault, 49 CAN. TAX J. 259 (2001) (discussing how stock options in Canada are more likely to be taxed under more favorable rates than they are in the United States). 


\section{A. Canadian Personal Income Tax Rules for Executive Stock Options}

Personal income taxation of stock options in Canada is notably less complex and more generous from the employee's perspective than in the United States. The applicable tax rules for stock options granted by publicly-traded companies are set out in section 7 and paragraph 110(1)(d) of the Canadian Income Tax Act. ${ }^{25}$ Section 7 pertains to the value and timing of the employment income inclusion and paragraph 110(1)(d) provides a deduction equal to one-half (reduced to one-fifth for the purposes of computing minimum $\operatorname{tax}^{26}$ ) of the income inclusion if certain conditions set out therein are met.

All employee stock options share the same general tax treatment in two areas. First, unlike employment income (e.g. annual salary or bonus income), which is taxable in the year it is received, there are no tax consequences when stock options are granted or when they vest; rather, under subsection 7(1), a tax liability does not arise until the time the option is exercised, at the earliest. ${ }^{27}$ The amount that must be included in income from employment upon exercise (or later, if certain conditions are met) is equal to the difference between the fair market value of the stock on the date the option is exercised and the strike price. Second, upon the sale of the stock acquired pursuant to the option, the difference between the proceeds of disposition of the stock and the fair market value of the stock on the date the option is exercised is taxed as a capital gain or capital loss, as the case may be. Under section 38 of the I.T.A., the taxable portion is calculated as onehalf of the capital gain or capital loss. ${ }^{28}$

There are, however, several exceptions to the general rules described above that affect both the amount and timing of the inclusion. One exception concerns stock options granted by a Canadian-controlled private corporation ("CCPC"). Under subsection $7(1.1)$, if certain conditions are met, the inclusion of the employment income benefit is deferred until the time that the shares are sold. ${ }^{29}$ In addition, there is a deduction equal to one-half of the inclusion if either the option strike price is equal to or greater than the fair market value of the share at the time of the grant (section 110(1)(d)) or if the shares acquired on exercise are held for a minimum two- year period before sale (paragraph $110(1)(\mathrm{d} .1)) .{ }^{30}$ As the backdating scandal mainly involves public corporations, we do not consider the tax treatment of options issued by CCPCs further.

${ }^{25}$ Income Tax Act, R.S.C. 1985, c. 1 (5th Supp.), as amended (“I.T.A.”), s. 7, 110(1)(d).

${ }^{26}$ Minimum tax serves a similar purpose to Alternative Minimum Tax in the United States, although it is imposed only on individuals (other than certain trusts). See infra note 39. Minimum tax is charged at the lowest marginal tax rate (currently fifteen percent) on an individual's adjusted taxable income less the individual's basic exemption (currently $\$ 40,000$ ). Adjusted taxable income is, essentially, taxable income adding back all or part of various specified tax preferences. For the purposes of adjusted taxable income, the tax preference in paragraph $110(1)(d)$ is recomputed to be two-fifths of the amount otherwise deducted under that provision (i.e., two-fifths of one-half of the stock option benefit). See I.T.A., s. 127.52(1)(h)(ii)(B). In the event that minimum tax exceeds tax otherwise payable, the excess may be carried forward seven years to reduce tax otherwise payable. Given that the minimum tax rate is a flat rate equal to the lowest marginal rate, relatively few higher-paid employees would be subject to minimum tax even if they have substantial stock option benefits (assuming that the stock option benefits are their only tax preference).

${ }^{27}$ I.T.A., s. 7(1).

${ }^{28}$ I.T.A., s. 38(a). From 1972 to 1988, the inclusion rate for capital gains and losses was one-half. In 1988, the rate rose to two-thirds and in 1990 the rate was subsequently increased to three-quarters. In February 2000 the rate was decreased to two-thirds and in October 2000 it was further decreased to one-half.

${ }^{29}$ I.T.A., s. 7(1.1).

${ }^{30}$ Even if both conditions are met, stock options granted by CCPCs qualify for either a deduction under paragraph 110(1)(d) or paragraph 110(1)(d.1) but not both. I.T.A., s. 110(1)(d), 110(1)(d.1). In addition, to qualify for the deduction under paragraph $110(1)(\mathrm{d})$, the option must be for "garden variety" 
For options issued by a public corporation, one-half of the stock option benefit is deductible under paragraph 110(1)(d) if three conditions are met: (1) the option strike price is equal to or greater than the fair market value of the share at the time of the grant; (2) the optioned shares are "plain vanilla" common shares; and (3) the employee deals at arm's length with the employer. ${ }^{31}$ In addition, for options issued by public corporations after February 27, 2000, and exercised prior to 4:00 p.m. (EST) on March 4, 2010, ${ }^{32}$ the employment income benefit is deferred until the time the shares are sold if the following conditions, stipulated in subsections 7(8) to (16) of the I.T.A. are met: (1) the recipient is a Canadian resident; (2) the underlying shares are traded on a Canadian or foreign prescribed stock exchange; and (3) the individual is entitled to the deduction under paragraph $110(1)(d) .{ }^{33}$ The deferral, however, is limited to the first $\$ 100,000$ worth $^{34}$ of options per year of vesting.

\section{B. US Tax Rules for Executive Stock Options}

In the United States, the taxation of employee stock options depends on their characterization as non-statutory stock options ("NSOs") or statutory stock options, which includes incentive stock options ("ISOs") and employee stock purchase plans ("ESPPs"). ${ }^{35}$ There is no difference in the treatment of options granted by a public corporation and a private corporation. ${ }^{36}$

In order for an option to be treated as an ISO, a number of requirements must be met including: (1) the exercise price must not be less than the fair market value of the stock at the time of the grant; (2) the exercised shares must be held for the longer of two years from the grant date or one year from the exercise date; and (3) the combined value, as determined by the fair market value of the underlying shares on the grant date, that can be acquired for the first time in any calendar year (i.e., in the year of vesting) cannot exceed US $\$ 100,000 .^{37}$ For an ISO, there are no income tax consequences until the time the shares are sold, ${ }^{38}$ unless the Alternative Minimum Tax ("AMT") ${ }^{39}$ applies. Upon the

common shares and the employer and employee must deal at arm's length both before and after the exercise of the options. I.T.A., s. 110(1)(d).

${ }^{31}$ I.T.A., s. $110(1)(\mathrm{d})$.

${ }^{32}$ In the March 4, 2010 federal budget, it was announced that subsections 7(8) to (15) of the I.T.A. will be repealed with effect for options exercised after 4 p.m. on that day. Sustaining Canada's Economic Recovery Act, R.S.C. 2010, c. 25, s. 39.

${ }^{33}$ I.T.A., s. $110(1)(\mathrm{d})$.

${ }^{34}$ The value is based on the fair market value of the underlying shares at the time the options are granted.

${ }^{35}$ See generally I.R.C. $\S 83$ (2006) (tax rules applicable to NSOs); I.R.C. § 421 (2006) (tax rules applicable to ISOs); I.R.C. $\S 422$ (2006) (further tax rules applicable to ISOs). ESPPs are generally not of interest with respect to the backdating discussion since they are not granted to employees, but rather the employer's shares are made available to all employees to purchase through payroll deductions. Consequently, our discussion will be limited to ISOs and NSOs.

${ }^{36}$ See I.R.C. $\$ \S 83,421,422(2006)$.

${ }^{37}$ I.R.C. $\$ \S 422(a)(1),(b)(4),(d)(1)(2006)$. To the extent that the value (so determined) of the stock options exceeds US $\$ 100,000$, the excess options are treated as NSOs. See I.R.C. $\S \S 422(d)(1), 83$ (2006).

${ }^{38}$ See I.R.C. $\$ 421(\mathrm{a})(1)$ (2006).

${ }^{39}$ The AMT is a tax designed to ensure that no taxpayer - whether individual or corporate - may disproportionally benefit from certain tax preferences. See $\S$ I.R.C. $\S \S 56,58-59$ (2006); I.R.C. 55, 57 (West 2011). Thus, a taxpayer must pay the greater of (i) his or her regular tax liability or (ii) his or her tentative minimum tax liability, calculated under the AMT rules. See I.R.C. $\$ 55$ (West 2011). To be precise, the AMT imposed is the amount by which the tentative minimum tax liability exceeds the regular tax liability. $I d$. The tentative minimum tax liability is calculated by recomputing regular tax liability, first by 
sale of the shares, the difference between the sale price and the exercise price under the option is treated as a capital gain, and since the shares must have been held for at least one year, the gain is taxed at the long-term capital gains rate of fifteen percent. ${ }^{40}$

An option award that does not, at the time of grant, meet the requirements of an ISO is taxed as an NSO. ${ }^{41}$ If an NSO has a readily ascertainable fair market value at the time of grant, the difference between the option's value and the amount paid by the grantee is taxed as income in the year of the grant or in the year that the option is exercised, depending on the taxpayer's election. ${ }^{42}$ However, in order for an option to have a readily ascertainable fair market value it must be either publicly traded or meet the following four conditions: (1) be transferable; (2) be exercisable in full on the grant date; (3) not be subject to any conditions that affect the value of the option (e.g., vesting and transferability restrictions); and (4) the fair market value of the underlying share must be readily determinable. ${ }^{43}$ Since NSOs are not generally publicly traded and fail to meet any of the first three conditions, most NSOs are not taxable at grant.

If an employee exercises options that are otherwise qualified as ISOs but then disposes of the shares within one year of exercise or within two years of when the options were granted, the employee stock option benefit (as determined above for a NSO) is not included in income until the time of sale of the shares and the difference between the sale proceeds and the fair market value of the shares at the time of exercise is taxed as a short-

adding back to taxable income tax preference items and by making certain adjustments in order to determine the alternative minimum taxable income ("AMTI"), then by applying the appropriate AMT rate to the amount by which AMTI exceeds the taxpayer's exemption amount. I.R.C. § 55(b) (West 2011). The AMT rate for individuals is $26 \%$ of such amount up to $\$ 175,000$ and $28 \%$ of any excess. I.R.C. $\S 55(b)(1)$ (West 2011). For individuals, the exemption amount depends on whether the individual is married and filing a joint return (in which case the amount is $\$ 45,000)$ or is a surviving spouse $(\$ 45,000)$ or is single $(\$ 33,750)$. I.R.C. $\S 55(\mathrm{~d})$ (West 2011). The exemption amount begins to be phased out when AMTI exceeds a threshold ( $\$ 150,000$ for a married individual filing a joint return; $\$ 112,500$ for a single individual). Id. The deferral of the income inclusion for an ISO is an adjustment in computing AMTI, resulting in the addition to regular taxable income in the tax year in which the option is exercised of an amount equal to the difference between the fair market value of the shares and the exercise price of the option. I.R.C. § 56(b)(3) (2006). However, where the exercise of the option and the sale of the shares occur in the same year, and the sale price for the shares is less than the value of the shares at the time the option was exercised, ISO treatment is not available since the holding period requirement has not been met. The amount included in income (for both regular tax and AMT purposes) is the difference between the sale price of the share and the strike price under the option. I.R.C. $\S \S 56(b)(3) ; 422(c)(2)$ (2006). The long-term capital gains rate remains applicable for AMT purposes; in other words, the reduced rate is not treated as a tax preference for AMT purposes. I.R.C. $\S 1(\mathrm{~h})$ (2006); I.R.C. § 55(b)(3) (West 2011). Certain AMT may be carried forward and applied to reduce the general tax payable in subsequent years (to the extent that the general tax exceeds the tentative alternative minimum tax liability for the subsequent year). See I.R.C. $§ 53$ (2006 \& Supp. III 2009) (allowing carry forward for a credit for the prior year's minimum tax liability that resulted from certain timing differences). See infra subpart III.D (illustrating in Example 4 the effect of AMT); see generally Francine J. Lipman, Incentive Stock Options and the Alternative Minimum Tax: The Worst of Time, 39 HARV. J. ON LEGIS. 337 (2002) (providing a detailed discussion of the AMT and its application to ISOs).

${ }^{40}$ I.R.C. $§ 1$ (h) (2006). Prior to 2003, the long-term capital gains rate was generally $20 \%$. In 2003 , the rate was reduced to $5 \%$ for individuals in the lowest two income brackets and $15 \%$ for all others. In 2008, the long-term capital gain rate for individuals in the lowest two tax brackets (currently 5\% and 15\%) was further reduced to zero. These reduced rates are currently effective until the end of 2012. Tax Relief, Unemployment Insurance Reauthorization, and Job Creation Act of 2010, Pub. L. No. 111-312, 124 Stat

3296 (extending reduced rates from the end of 2010 until the end of 2012).

${ }^{41}$ See I.R.C. $\$ \S 83,422(\mathrm{~d})(1)(2006)$.

${ }^{42}$ I.R.C. $\$ 83(a)-(b)$ (2006).

${ }^{43}$ Treas. Reg. $§ 1.83-7$ (b)(2) (as amended in 2004). 
term capital gain. ${ }^{44}$ Short-term capital gains are taxed at the individual's ordinary income tax rate. ${ }^{45}$ However, if the shares decline in value between the time of exercise and the time of sale, then the employee benefit is limited to the difference between the sale proceeds and the strike price under the option. ${ }^{46}$

Prior to the introduction of $\S 409$ A to the Code in late 2004, if the fair market value of an NSO was not readily ascertainable at the time of grant, no income was recognized for tax purposes until the option was exercised, regardless of whether or not the options were in-the-money on the grant date. ${ }^{47}$ In either case, upon exercise, the amount included in income (and subject to tax at normal tax rates as compensation income) was equal to the difference between the strike price and the fair market value of the stock on the date of exercise. ${ }^{48}$ This amount was also added to the basis of the stock for capital gains purposes. ${ }^{49}$ Any further taxation was deferred until the underlying shares were sold, when the gain or loss-i.e., the difference between the sale price and the fair market value on the exercise date-was taxed as a capital gain or loss. ${ }^{50}$ If the shares were held for one year or less, the gain was taxed as a short-term capital gain (taxable at regular marginal rates) whereas if the shares were held for more than a year, the applicable rate was the long-term capital gains rate, which is currently fifteen percent. ${ }^{51}$ This tax treatment remains applicable to options provided that they are not inthe-money at the grant date.

Following corporate and accounting scandals such as Enron, Tyco, and WorldCom, the American Jobs Creation Act of 2004 added $\S 409$ A to the Code, ${ }^{52}$ which radically changed the taxation of deferred compensation, including discounted stock options. ${ }^{53}$ I.R.C. $§ 409$ A provides in part:

$\S 409 \mathrm{~A}$. Inclusion in gross income of deferred compensation under nonqualified deferred compensation plans

(a) Rules relating to constructive receipt

(1) Plan failures

(A) Gross income inclusion

(i) In general.- If at any time during a taxable year a nonqualified deferred compensation plan-

(I) fails to meet the requirements of paragraphs (2), (3), and (4), or

${ }^{44}$ I.R.C. $\$ 421(b)(2006)$.

${ }^{45}$ See I.R.C. § 1(h) (2006); I.R.C. § 1222 (West 2011).

${ }^{46}$ See I.R.C. $\S 421$ (b) (2006).

${ }^{47}$ See I.R.C. $\$ \S 409 A ; 83(\mathrm{e})(2006)$.

${ }^{48}$ See I.R.C. $\$ 83$ (2006).

${ }^{49}$ See id.

${ }^{50}$ See I.R.C. $\$ 1221$ (2006).

${ }^{51}$ See I.R.C. § 1(h) (2006); I.R.C. § 1222 (West 2011).

${ }^{52}$ American Jobs Creation Act of 2004, Pub. L. No. 108-357, § 885, 118 Stat. 1418, 1635-42.

${ }^{53}$ Although the new regime was effective October 2004, corporations were essentially given until December 31,2006 , to modify any unvested and unexercised stock options to ensure compliance with $\S 409 \mathrm{~A}$ by increasing the exercise price to the fair market value of the stock on the grant date; however, if any payments were made to compensate employees for the revised option exercise price, these payments were subject to $§ 409 A$. See I.R.C. § 409A (2006). 
(II) is not operated in accordance with such requirements,

all compensation deferred under the plan for the taxable year and all preceding taxable years shall be includible in gross income for the taxable year to the extent not subject to a substantial risk of forfeiture and not previously included in gross income.

(ii) Application only to affected participants.-Clause (i) shall only apply with respect to all compensation deferred under the plan for participants with respect to whom the failure relates.

(B) Interest and additional tax payable with respect to previously deferred compensation

(i) In general.- If compensation is required to be included in gross income under subparagraph (A) for a taxable year, the tax imposed by this chapter for the taxable year shall be increased by the sum of-

(I) the amount of interest determined under clause (ii), and

(II) an amount equal to 20 percent of the compensation which is required to be included in gross income.

(ii) Interest.-For purposes of clause (i), the interest determined under this clause for any taxable year is the amount of interest at the underpayment rate plus 1 percentage point on the underpayments that would have occurred had the deferred compensation been includible in gross income for the taxable year in which first deferred or, if later, the first taxable year in which such deferred compensation is not subject to a substantial risk of forfeiture.

I.R.C. $\S 409$ A applies to a broad range of deferred compensation, although it also provides a number of exceptions, including employee stock options that are granted notin-the-money. ${ }^{54}$ However, in-the-money options (including backdated options that appear to be not-in-the-money options) are caught by the section. Under $\S 409 \mathrm{~A}(\mathrm{a})(1)(\mathrm{A})$, the "compensation deferred under the plan" must be included in the employee's gross income "for the taxable year to the extent not subject to a substantial risk of forfeiture and not previously included in gross income." ${ }^{55}$ In addition to the income inclusion, $\S 409 \mathrm{~A}(\mathrm{a})(1)(\mathrm{B})$ provides that the tax payable on such income is increased by "premium interest tax" penalty tax) equal to twenty percent of the compensation required to be included in gross income. ${ }^{57}$ Generally speaking, a taxpayer must include in income an amount attributable

\footnotetext{
${ }^{54}$ See supra note 4 (discussing the difference between in-the-money and not-in-the-money options).

${ }^{55}$ I.R.C. $\S 409$ (a)(1)(A) (2006).

${ }^{56}$ In-the-money options will not be subject to premium interest tax. Premium interest tax is computed only for the period from the time of vesting to the time that $\S 409 \mathrm{~A}$ is breached. See I.R.C. $\S 409 A(a)(1)(B)(i i)$ (2006). Since in-the-money options breach $\S 409 A$ when granted (i.e., at the time of vesting, if the options are vested at the time granted, or otherwise prior to vesting), there is no period during which premium interest tax is computed.

${ }^{57}$ I.R.C. § 6662(a) (West 2011).
} 
to a grant of in-the-money stock options in the year that the options vest and in every subsequent year up to and including the year of exercise (to the extent not included in income in a previous year). Neither $\S 409 \mathrm{~A}$ nor the final regulations issued to date under the statute specify the amount included in income (and the basis for the additional tax). However, the proposed regulations indicate that the amount to be included is the intrinsic value of the option on the last day of the employee's taxation year in which the option vests and any subsequent year in which a vested option remains unexercised, and, in the year of exercise, the actual value on the exercise date. ${ }^{58}$ The income inclusion and penalty tax apply regardless of when (or if) the options are ultimately exercised. ${ }^{59}$ In effect, $\S 409 \mathrm{~A}$ provides for income inclusion (and a corresponding penalty tax) in each year following the year in which an option vests, and until and including the year of exercise, depending on the value of the underlying shares on December 31 (or the date that the options are exercised in) of the subsequent year. ${ }^{60}$

${ }^{58}$ See Prop. Treas. Reg. § 1.409A-4(b)(6), 73 Fed. Reg. 74.380, 74.399 (Dec. 5, 2008). Prior to the issuance of the proposed regulation, the IRS had issued Notice 2005-1 setting forth the IRS's initial guidance on the provision. I.R.S. Notice 2005-1, 2005-1 C.B. 274. Neither that notice nor the final regulations released on April 10, 2007 (applicable to taxation years beginning after December 21, 2008) addressed the calculation of the amount included in income under $\$ 409 \mathrm{~A}$. Interim guidance in Notice 2006-100 (applicable to the 2005 and 2006 taxation years) provided that the intrinsic value of a vested stock option on the year-end of the employee (i.e., December 31) is the basis for the income inclusion, premium interest tax (if applicable) and additional tax, assuming that the options were not modified to avoid the application of $\S 409$ A. I.R.S. Notice 2006-100, 2006-2 C.B. 1109. The preamble to the proposed regulation states in part: "The Treasury Department and the IRS recognize that the spread [i.e., intrinsic value] generally is less than the fair market value of the stock right, which is used for purposes of determining the amount taxable under other Code provisions .... However, because these types of stock rights typically will fail to comply with section 409A(a) in multiple years, a taxpayer who holds such a stock right generally will be required to include amounts in income under section 409A in more than one taxable year. Therefore, the Treasury Department and the IRS believe that it is more appropriate to use the spread for purposes of applying section 409A(a) to stock rights.” Prop. Treas. Reg. § 1.409A-4(b)(6), 73 Fed. Reg. 74.380, 74.386 (Dec. 5, 2008).

${ }^{59}$ If the options expire unexercised - in other words, the employee's right to the deferred income is permanently lost - the employee is entitled to a deduction at that time equal to the amounts previously included in income under $\S 409 \mathrm{~A}$. However, there is no deduction for the additional tax previously assessed. See 2008-51 I.R.B. 1297, 1336-37 (Dec. 22, 2008).

${ }^{60}$ Consider the following simple example. Suppose that on December 31, 2009, an employee of XCo receives 30,000 employee stock options at an exercise price of $\$ 10$ per share. The options have a tenyear life and one-third of the options each vest on December 31 of 2010, 2011, and 2012. Suppose that the shares have a fair market value on December 31, 2009, of \$12 per share (i.e., the options are granted in-themoney or, alternatively, the options may be backdated to an earlier date (such as December 1,2009) when the fair market value of the shares was $\$ 10$ per share). Because the options were in-the-money on December 31, 2009 , the actual grant date, they would be subject to tax under $\S 409 A$. See I.R.C. $\S 409 A$ (2006). Suppose that on December 31, 2010, the XCo shares are trading at $\$ 14$ per share. On that date, 10,000 options vest (i.e., are no longer subject to a substantial risk of forfeiture). Because the options were in-the-money on December 31, 2009, they would be subject to tax under $\S 409$ A. See id. Consequently, the employee must include in gross income in 2010 the amount of $\$ 40,000$ ( $\$ 4$ per share $\times 10,000$ shares), which would be subject to tax at the employee's marginal rates. In addition, the employee would have to pay an "additional tax" of $\$ 8,000$ (20\% of $\$ 40,000)$. No premium interest tax is payable. See supra note 56. Suppose further that on December 31, 2011, when an additional 10,000 options vest, the fair market value of the shares of $\mathrm{XCo}$ is $\$ 17$ per share. The employee would have to include $\$ 100,000$ in income in 2011 [ $\$ 7 \times 20,000-$ $\$ 40,000$ (the amount included in 2010)]. This amount would be subject to tax at the employee's marginal rate and, in addition, the employee would have to pay a tax of $\$ 20,000$. Finally, suppose on December 31, 2012 , when the final 10,000 options vest, the shares of XCo are trading at $\$ 15$ per share. The employee would have to include $\$ 10,000$ in income for that year $[\$ 5 \times 30,000-\$ 140,000$ (the aggregate amounts included in income in 2011 and 2012)] plus $\$ 1,000$ additional tax. In a subsequent year in which the options remain outstanding, if the shares of XCo are trading above $\$ 15$ per share, the employee may be subject to 


\section{Tax Regime and Backdated Options}

Based on the above discussion, the most preferential compensation regime from an executive's tax perspective in either Canada or the United States is one in which the options are granted not-in-the-money (or for our purposes, backdated to appear as such).

In Canada, not only is there no super-inclusion or penalty tax regardless of the option's exercise price relative to the value of the shares on the option grant date, but also provided that the options are at-the-money (or backdated to appear as such), only onehalf of the option benefit is included in income for tax purposes regardless of the length of time that the shares are held after exercise. ${ }^{61}$ This demonstrates a clear tax advantage for stock option compensation, provided that the options are granted not-in-the-money (or reported as such).

In Canada, employees who receive backdated stock options, the equivalent of inthe-money options (assuming that the fair market value of the shares on the real grant date exceeds the strike price under the option), may be reassessed by the Canada Revenue Agency not only to deny any deduction claimed under paragraph $110(1)(\mathrm{d})$, but also to include the employee benefit from the option in income in an earlier year than that in which the employee reported the benefit (and offsetting deduction) for tax purposes. Such reassessment would also include interest, compounded daily at a relatively high rate. Furthermore, an employee who knowingly received backdated options and reported them as if they were not-in-the-money could be subject to penalties ${ }^{62}$ for gross negligence and perhaps even charged with tax evasion. ${ }^{63}$

further income inclusion and additional tax under $\S 409$ A. Finally, suppose in 2017, the employee exercises the options when the shares are trading at $\$ 21$ per share (and on no previous December 31 had the trading price of XCo shares reached that amount), the employee would be required to include in income $\$ 330,000$ less the aggregate amounts included in gross income under $\S 409 \mathrm{~A}$ in previous years, plus additional tax at the rate of $20 \%$ on such amount. See I.R.C. $\S 409 A$ (2006).

${ }^{61}$ See I.T.A., s. $110(1)(\mathrm{d})$.

${ }^{62}$ The expected cost of any such penalties would presumably be a consideration in whether or not an executive decides to engage in backdating. In Canada, an executive faces a penalty amounting to $50 \%$ of the increase in tax payable caused by the backdating in that taxation year (assuming that the improper reporting on the part of the employee amounts to gross negligence). I.T.A., s. 163(2). In the United States, the penalty would likely be less than in Canada, as it is calculated as $20 \%$ of the underpayment of tax in that taxation year for negligence or disregard of the rules or regulations, or $40 \%$ of the underpayment of tax in the case of a gross valuation misstatement. See I.R.C. $\S \S 6662(a)$, (h) (West 2011). The underpayment of tax in the United States will likely be less than in Canada because backdating provides less of a benefit in the United States. See Compton et al., supra note 3, at 373-74. In addition to quantifying the penalty, it is important to consider the probability of such a penalty being applied. Given the evidence to date, it is more likely that an executive in the United States will be caught for backdating options than an executive in Canada. If the backdating is not caught by securities regulators, it is highly unlikely that the Canada Revenue Agency will independently investigate possible backdating behavior. Canada's securities regulators are generally considered to be less aggressive in investigating backdating behavior than the United States' Securities and Exchange Commission. Furthermore, the Internal Revenue Service has given backdated stock options specific recognition as a Tier I issue for its Large and Mid-Size Division. I.R.S. Treas. Dir. LMSB 04-0407-036 (June 15, 2007). The heightened probability of being caught by either regulatory body in the United States likely contributes to the decreased incidence of backdated or manipulated option grants in the United States, ceteris paribus. See also infra note 65 and accompanying text (discussing the positive correlation between compliance and the size of penalty if caught).

${ }^{63}$ The implications of this could reach even further since it previously has been found that noncompliant corporations are three times more likely than compliant corporations to be managed by executives who have evaded personal taxes. See David Joulfaian, Corporate Tax Evasion and Managerial Preferences, 82 REv. ECON. \& STAT. 698, 698-99 (2000). 
In the United States, employees who receive backdated ISOs or backdated NSOs are, in fact, receiving deferred compensation subject to tax under I.R.C. § 409A. In addition, ISOs that are backdated do not meet the necessary requirements for preferential tax treatment (assuming that the shares are held for at least a year after exercise) and instead must be treated as backdated NSOs for tax purposes. However, rank and file employees who receive ISOs may not be aware they were granted discounted stock options and could be reassessed on the basis that a tax liability arose in the year the options vested (and subject to an income inclusion and additional tax under I.R.C. $\S 409 \mathrm{~A})$ in addition to the year the shares are ultimately sold. The relative share values at the time of vesting (and December 31 of each year that vested options remain unexercised) give rise to significant tax differences upon exercise or sale. The corporation's executives may have knowingly received backdated options and reported them as if they were at-the-money. In addition to the accelerated reporting under I.R.C. $\S 409 \mathrm{~A}$, such executives could be subject to gross negligence penalties and perhaps charged with tax evasion. ${ }^{64}$ Based on the standard model of tax evasion by Allingham and Sandmo, ${ }^{65}$ where compliance is positively associated with the size of penalty assessed if caught, one might expect that the punitive consequences of I.R.C. § 409A should have reduced the incidence of backdating in the United States. However, there continues to be some evidence of backdating in the United States, ${ }^{66}$ suggesting that executives may perceive there to be a low risk that the IRS will apply I.R.C. $§ 409$ A to backdated options.

\section{QUANTIFYING THE BENEFITS OF BACKDATING: EXAMPLES}

To demonstrate the tax consequences of backdated options in each country, consider the following example. An executive at a publicly traded company is the recipient of an option grant for 30,000 shares which expires ten years after the date of the grant. This award is dated as having been granted on October 16 when the share price was $\$ 14.25$, but in reality was granted on November 30 when the share price was $\$ 18.40$. For simplicity and ease of comparison, we assume that the individual faces a marginal tax

${ }^{64}$ See supra note 62 and accompanying text.

${ }^{65}$ See generally Michael G. Allingham \& Agnar Sandmo, Income Tax Evasion: A Theoretical Analysis, 1 J. PUB. ECON. 323 (1972) (discussing how compliance with reporting regulations increases as penalties for evasion increase). The Allingham-Sandmo model has been extended in a number of dimensions over the last thirty years. See generally Kim Border \& Joel Sobel, Samurai Accountant: A Theory of Audit and Plunder, 54 REV. ECON. STUD. 525 (1987) (discussing the positive relationship between a tax collector's threat of audit and a taxpayer's truthful income reporting); Helmuth Cremer, Maurice Marchand \& Pierre Pestieau, Evading, Auditing and Taxing: the Equity-Compliance Tradeoff, 43 J. PuB. ECON. 67 (1990) (analyzing the social welfare elements of tax parameters that try to maximize compliance); Dilip Mookherjee \& Ivan P.L. Png, Optimal Auditing, Insurance and Redistribution, 104 Q. J. Econ. 399 (1989) (incorporating the role of moral hazard in the penalty-compliance analysis); Isabel Sanchez \& Joel Sobel, Hierarchical Design and Enforcement of Income Tax Policies, 50 J. PuB. ECON. 345 (1993) (analyzing the role that hierarchy within the government plays in setting compliance-conscious tax policies); Suzanne Scotchmer, Audit Classes and Tax Enforcement Policy, 77 AM. ECON. REv. 229 (1987) (analyzing the regressive bias of a compliance scheme that consists of different audit classes); Greg Trandel \& Arthur Snow, Progressive Income Taxation and the Underground Economy, 62 ECON. LETTERS 217 (1999) (arguing that the source of one's income can contribute to one's likelihood of successfully avoiding penalties for underreporting); Harry Watson, Tax Evasion and Labor Markets, 27 J. PuB. ECON. 231 (1985) (discussing how different labor markets have different potentials for tax evasion). For an additional survey of this literature, see James Andreoni, Brian Erard, \& Jonathan Feinstein, Tax Compliance, 36 J. ECON. LiTERATURE 818, 818-19, 823-25 (1998); Joel Slemrod \& Shlomo Yitzhaki, Tax Avoidance, Evasion, and Administration, in 3 HANDBOOK OF Public ECONOMics 1423, 1429-36 (A. J. Auerbach and M. Felstein eds., 2002).

66 See supra note 8 and accompanying text. 
rate of twenty-nine percent in both countries. It is also assumed, in the case of the U.S. executive, that such options expire or are all exercised prior to the introduction and application of I.R.C. $\S 409$ A. ${ }^{67}$ For the purposes of demonstrating the impact, if any, of minimum tax in Canada and AMT in the United States, it is assumed that the executive has gross taxable income not derived from any issuance, exercise or sale of stock options or the underlying stock, of $\$ 150,000$ and does not benefit from any tax preference other than the preference (if any) associated with employee stock options. Based on this assumption, minimum tax will not apply in any of the examples and AMT will apply only in the fourth example.

Each example compares four scenarios in each country: (1) at-the-money backdated options; (2) at-the-money currently dated options; (3) fixed value options; and (4) currently dated in-the-money options with the same strike price as the backdated options (i.e., if the employee properly reported the backdated options for tax purposes). They each set out in the last row the "Canadian advantage," if any, that the Canadian executive receives compared to his U.S. counterpart in the same scenario. In all cases where an advantage exists (except the fourth example, where the advantage stems from the application of AMT in the U.S. in the year of exercise), it is due exclusively to the deduction that the Canadian executive enjoys under I.T.A. paragraph 110(1)(d), for which there is no U.S. equivalent.

\section{A. Example 1-Exercise and Sale on Same Date}

The first example assumes that the individual exercises the options and sells the resulting shares on the same date, which is a common occurrence. ${ }^{68}$ The sale price of the shares on the date of exercise is $\$ 22.77$. Table 1 summarizes the tax consequences of this example in Canada and the United States.

${ }^{67}$ Although $\S 409$ A was introduced in 2004, corporations were given until the end of 2006 to bring unvested and unexercised stock options into compliance with $\S 409$ A. See supra note 53.

${ }^{68}$ See, e.g., Jennifer N. Carpenter \& Barbara Remmers, Executive Stock Option Exercises and Insider Information, 74 J. Bus. 513, 514 (2001); Eli Ofek and David Yermack, Taking Stock: Equity-based Compensation and the Evolution of Managerial Ownership, 55 J. FIN. 1367, 1368 (2000). The exception to this general trend occurred prior to May 1991 in the United States when insiders had to hold the stock they acquired through option exercise for six months. See Carpenter \& Remmers, supra. 
Table 1: Summary of Tax Implications from Examples 1 and 2: Exercise and Sale on the Same Date

\begin{tabular}{|c|c|c|c|c|c|c|c|c|}
\hline \multirow[b]{3}{*}{ \# of Options } & \multicolumn{4}{|c|}{ Canada } & \multicolumn{4}{|c|}{ US } \\
\hline & $\begin{array}{c}\text { At-the-Money } \\
\text { Backdated }\end{array}$ & $\begin{array}{l}\text { At-the-Money } \\
\text { At Exerci }\end{array}$ & $\begin{array}{l}\text { Reduced } \\
\text { Share }\end{array}$ & In-the-Money & $\begin{array}{l}\text { At-the-Money } \\
\text { Backdated }\end{array}$ & \multicolumn{2}{|c|}{$\begin{array}{c}\text { At-the-Money Reduced Share } \\
\text { At Exercise/Sale }\end{array}$} & In-the-Money \\
\hline & 30,000 & 30,000 & 23,234 & 30,000 & 30,000 & 30,000 & 23,234 & 30,000 \\
\hline Exercise Price & $\$ 14.25$ & $\$ 18.4$ & $\$ 18.4$ & $\$ 14.25$ & $\$ 14.25$ & $\$ 18.4$ & $\$ 18.4$ & $\$ 14.25$ \\
\hline $\begin{array}{l}\text { Total Income } \\
\text { Benefit }\end{array}$ & $\$ 255,600$ & $\$ 131,100$ & $\$ 101,533$ & $\$ 255,600$ & $\$ 255,600$ & $\$ 131,100$ & $\$ 101,533$ & $\$ 255,600$ \\
\hline Deduction & $\$ 127,800$ & $\$ 65,550$ & $\$ 50,766$ & $\$-$ & N/A & N/A & N/A & N/A \\
\hline $\begin{array}{l}\text { Taxable income } \\
\text { benefit }\end{array}$ & $\$ 127,800$ & $\$ 65,550$ & $\$ 50,766$ & $\$ 255,600$ & $\$ 255,600$ & $\$ 131,100$ & $\$ 101,533$ & $\$ 255,600$ \\
\hline
\end{tabular}

Canadian

advantage $(\%)$

20.42

20.42

20.42 
For a Canadian executive, if the option is "successfully" reported as an at-the-money grant awarded on October 16 with a strike price of $\$ 14.25$, then the income benefit subject to tax is calculated as the difference between the fair market value of the shares on the date of exercise and the strike price multiplied by the number of options awarded, which is $\$ 255,600$. The individual claims a deduction under paragraph $110(1)(d)$, which reduces the income inclusion to $\$ 127,800$. As the sale price is equal to the price of the shares at the time the options were exercised, there is no capital gain or loss to report. The individual faces a tax liability of $\$ 37,062$, and the net aftertax benefit to the executive is $\$ 218,538$. This is reported in the first column of Table 1 .

If, instead, the option had been properly dated as November 30 and had an associated strike price of $\$ 18.40$ (the fair market value on that date), then the individual would have reported an income benefit of $\$ 131,100$, claimed the deduction under paragraph 110(1)(d), which would have reduced the overall income inclusion to $\$ 65,550$, resulting in a tax liability of $\$ 19,009.50$ and a net after-tax benefit to the employee of $\$ 112,091.50$.

This example assumed that the option plan is based on receiving a fixed number of shares $(30,000)$ as part of a fixed-share option plan. However, as an additional wrinkle, Column 3 considers the difference in value of backdating if the employer used a fixed-value option plan. Under a fixed-value option plan, an executive is given a fixed dollar amount of options (rather than a fixed number of options). In this example, it is assumed that under a fixed-value option plan the executive is to receive $\$ 241,050$ worth of options. ${ }^{69}$ If the options are granted on November 30 with a strike price of $\$ 18.40$, this would give the executive 23,234 options, while if the executive received the options backdated to the October 16 strike price of $\$ 14.25$, he or she would receive 30,000 options. This represents a twenty-nine percent increase $(6,767)$ in the number of options received as a result of backdating. Thus, if the corporation awarded fixed-value options, then at the strike price of $\$ 18.40$, the individual would have only received 23,234 options (rather than 30,000 options), which when exercised would have resulted in $\$ 14,722.22$ of tax liability and a net aftertax benefit of $\$ 86,810.36$.

Finally, if the executive properly reported the backdated options as in-the-money options for tax purposes, thereby forgoing the deduction under paragraph $110(1)(\mathrm{d})$, the tax liability would have been $\$ 74,124$ and the net after-tax benefit would have been $\$ 181,476$.

In summary, the after-tax benefit to the Canadian executive of a backdated option is higher than in any other case. In fact, the after-tax value of the backdated option is $\$ 37,062$ higher than if the option were reported as being in-the-money and $\$ 106,447.50$ higher than an at-the-money option granted on November 30. If the corporation issued fixed value options, then had the option been properly awarded on November 30 rather than reported as being awarded on October 16, the individual would have received 23,234 options priced at $\$ 18.40$ rather than 30,000 priced at $\$ 14.25$ and would have obtained an after-tax benefit of $\$ 86,810.36$, the lowest of all cases.

In considering the case of the U.S. executive, since the individual exercised the options and sold the shares on the same day, this is a disqualified disposition of an ISO, and therefore the options would be taxed as NSOs and the income inclusion for the U.S. executive is included in the same taxation year as the disposition of the shares. In all cases, the resulting tax liability is greater than or equal to the tax assessed in Canada, assuming equivalent marginal rates. The most interesting point of this example is that prior to the introduction of I.R.C. $§ 409 \mathrm{~A}$, the net after-tax

\footnotetext{
${ }^{69} \mathrm{We}$ have assumed this amount for ease of calculation.
} 
benefit enjoyed by the executive is identical for the backdated option reported as an at-the-money option and the currently dated in-the-money option with the same $\$ 14.25$ strike price. Because there is no deduction in the United States comparable to paragraph 110(1)(d) of the I.T.A., the tax payable in these two cases is the same $(\$ 74,124)$, resulting in an after-tax benefit of $\$ 181,476$.

This example suggests that until the introduction of I.R.C. $\S 409$ A, and for tax purposes only, a U.S. executive would have been indifferent between backdated options and discounted options, but would have preferred either of these to at-the-money options granted on November 30. The example also implies that the personal income tax regime in Canada may cause an individual to prefer a backdated option over any other option type. ${ }^{70}$ In the United States, on the other hand, prior to the introduction of I.R.C. $\$ 409 \mathrm{~A}$, an individual would have been indifferent between a backdated option and an in-the-money option.

\section{B. Example 2-Vest Over Five Years, Sale on Same Date as Exercise}

In the second case, we extend our example to include the fact that the options vest at a rate of one-fifth (or 6,000 options) per year over five years. We maintain the assumption that the exercise date is the same as the date of sale. In this case, the tax treatment (and after-tax benefit) in both Canada and the United States is identical to that in Example 1. ${ }^{71}$

\section{Example 3-Vest Over Five Years, Sale in Same Year as Exercise}

In the third case, we extend Example 2 by changing the sale date to a date later in the same year as the exercise date. The price of the underlying shares on the exercise date is still $\$ 22.77$, and the sale price is assumed to be $\$ 25$. Table 2 summarizes the tax consequence of this example in Canada and the United States.

\footnotetext{
${ }^{70}$ While significant empirical research has been done on backdating in the United States, there has been almost no empirical work on this subject published in Canada. To our knowledge, Compton et al., supra note 3 , remains the only academic study on backdating in Canada, arguing that "[ $t]$ his void is likely not reflective of the lack of backdating or option timing in Canada" but that "[t]he primary reason for this dearth of research in Canada can be attributed to the differences in the availability of empirical data necessary to examine backdating in the United States and Canada." Compton et al., supra note 3, at 366, 376. For example, Siskinds LLP, a Canadian law firm specializing in class actions, has investigated stock option awards of a number of companies trading on the TSX and has found evidence of backdating behavior or other stock option manipulation in thirty-five companies and is investigating suspicious behavior in twentyfive others. Julius Melnitzer, Manipulation 'Serious Problem', Fin. Post, Sept. 19, 2007, at FP1. In addition, investment researchers found evidence of options timing among S\&P/TSX 60 companies: "on average, prices were 50 basis points higher 10 days before the grant date, and more than 100 basis points higher 15 days after the grant date." Sam La Bell \& Chris Silvestre, Veritas Investment Research, Stock Option Backdating: Could It Happen Here? 3 (2006).

Finally, a number of Canadian companies have voluntarily and proactively, albeit quietly, launched internal reviews of their options granting procedures. See Compton et al., supra note 3, at 378. However, the options dating practices of only a handful of companies have garnered media attention in Canada.

${ }^{71} \mathrm{Had}$ these options been issued or outstanding after 2004, the tax treatment in the United States would be radically different (and more severe) for in-the-money options due to the application of I.R.C. $§ 409$ A. See supra subpart II.B and accompanying notes.
} 
Table 2: Summary of Tax Implications from Example 3: Sale on Different Date in Same Year as Exercise

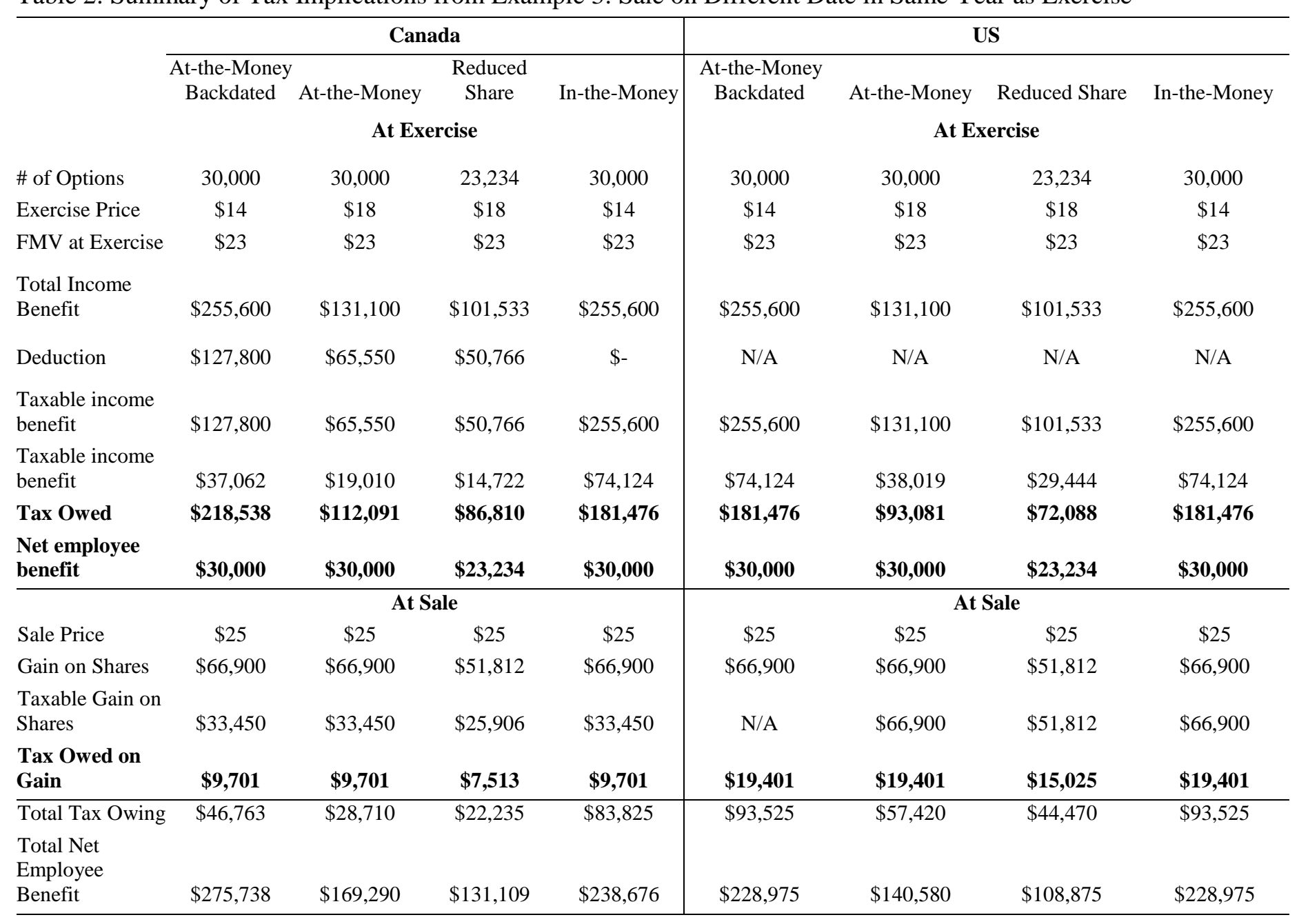

Canadian

advantage $(\%) \quad 20.42 \quad 20.42 \quad 20.42 \quad 4.24$ 
In Canada, if the options are exercised and sold in the same tax year, then the employee income benefit inclusion (and offsetting deduction under paragraph 110(1)(d), if applicable) is identical to that described in Example 1. In addition, the employee realizes a capital gain ${ }^{72}$ on the disposition of the shares, only one-half of which is subject to tax. In this example, the capital gain for all but the reduced share option award is $\$ 66,900$ [30,000 $\times(\$ 25.00-\$ 22.77)]$, giving rise to a taxable capital gain of $\$ 33,450$. This amount is taxed at the individual's marginal tax rate (assumed to be twenty-nine percent) for a total tax owing on the capital gain of $\$ 9,700.50$. The capital gain for the reduced share option award is $\$ 51,811.82$ for a total tax owing on the taxable portion of the gain of $\$ 7,512.71$. Because the tax treatment of the capital gain does not vary according to the underlying option characteristics, it does not affect the conclusions reached regarding the tax benefit of backdated options in Example 1. The highest after-tax benefit arises from the backdated at-the-money options, and the lowest from the fixed-value options granted on November 30 based on the $\$ 18.40$ strike price.

In the United States, since the executive held the shares for less than a calendar year, the individual will again not benefit from ISO treatment. For all the cases (ignoring the implications of I.R.C. $\S 409 \mathrm{~A}^{73}$ ), the employee benefit is the same as that summarized in Table 1. In addition, due to the sale price of $\$ 25.00$, the employee realizes a capital gain of $\$ 66,900$ on the disposition (the same amount as in Canada), except that because the employee held the shares for less than a year, the capital gain is a short-term capital gain and is subject to tax at the same marginal tax rate as other income (assumed to be twenty-nine percent).

\section{Example 4-Vest Over Five Years; Sale More Than One Year After Exercise}

In the fourth example, we extend Example 3 by changing the sale date to be more than one year after the exercise date. The price of the underlying share on the exercise date is still $\$ 22.77$, and the eventual sale price is assumed to be $\$ 25$, the same as in Example 3. Table 3 summarizes the tax consequence of this example in Canada and the United States.

In Canada, as the options are exercised and sold in different years, we now have to consider the role of the deferral introduced in 2000, assuming that the options are exercised prior to March 4, 2010. ${ }^{74}$ The amount that may be deferred is limited to the benefit arising on $\$ 100,000$ worth of stock options per year of vesting (based on the fair market value of the underlying stock when the options were granted).

In the first scenario-backdated options that are reported as being at-the-money-the maximum number of stock options vesting in any one year that can benefit from the deferral is 7,017 , which is calculated by dividing the $\$ 100,000$ limit by $\$ 14.25$, the purported fair market value of the underlying stock when the options were granted. Since only 6,000 options vest each year, the entire employee benefit arising on the exercise of all 30,000 options is deferred from the year that the options are exercised until the year of sale. Upon the sale of the stock, the individual includes the deferred income benefit in his income, claims the fifty percent deduction under

\footnotetext{
${ }^{72}$ The gain realized is assumed to be a capital gain rather than an ordinary gain, although this characterization may be a matter of some dispute. See generally Daniel Sandler, The Adventure in Venture Capital: Capital Gains vs. Ordinary Income, 42 TAX NOTES INT'L 621 (2006) (discussing the history in the common law system of failing to completely distinguish between ordinary income and capital gains).

${ }_{73}$ As in Example 2, I.R.C. $\$ 409$ A would radically alter the tax treatment of in-the-money options.

${ }^{74}$ See I.T.A., s. 7(1.1).
} 
paragraph $110(1)(d)$ of the I.T.A., ${ }^{75}$ and pays the tax owing on the taxable income benefit in the amount of $\$ 37,062$ and the taxable capital gain of $\$ 9,700.50$. The total tax paid is $\$ 46,762.50$ and the net employee benefit is $\$ 275,737.50$. The absolute quantum of the benefit is the same as in Example 3, not taking into account the time value of money. In this example, however, since the tax on the stock option benefit is deferred until a later year (since the shares are sold in a later year), the relative quantum of the benefit is greater than in Example 3.

If instead, the option had been properly dated as November 30 and had an associated strike price of $\$ 18.40$, then the deferral is calculated using the fair market value at grant of $\$ 18.40$ rather than $\$ 14.25$. Consequently, the maximum number of stock options vesting in any one year that can benefit from the deferral is 5,434 , which is calculated by dividing the $\$ 100,000$ limit by $\$ 18.40$. Since this number is less than the 6,000 options that vest each year under this plan, not all of the stock option benefit arising in the year of exercise can be deferred until the year of sale. The maximum benefit that the individual can defer is $\$ 118,732.90[5 \times 5,434 \times(\$ 22.77-\$ 18.40)]$. The individual defers this amount to the year in which the shares are sold, but must include the remaining employee benefit $(\$ 12,367.10$, representing the difference between the total employee benefit of $\$ 131,100$ and the maximum deferral of $\$ 118,732.90)$ in the year of exercise. In the year of exercise, the individual can claim the fifty-percent deduction under paragraph 110(1)(d) of the I.T.A. ${ }^{76}$ reducing the amount added to taxable income to $\$ 6,183.55$ with associated tax liability of $\$ 1,793.23$. Since the stock has not been sold at this time, the executive must pay this tax liability from other income; the amount is small enough that this should not be onerous. Upon the sale of the stock, the individual includes the deferred stock option benefit in income, claims the 50\% deduction under paragraph 110(1)(d) of the I.T.A., ${ }^{77}$ and pays the tax owing on the stock option benefit in the amount of $\$ 17,216.27$ and the taxable capital gain of $\$ 9,700.50$. The absolute quantum of the economic benefit to the employee in this scenario is the same as in Example 3, but part of it must be paid at exercise rather than being deferred to the year in which the shares are sold (so that, as in the case of the backdated at-the-money options, the relative quantum of the benefit is greater than in Example 3).

Under the reduced share option, the outcome is similar to the first scenario in this example, with the individual deferring the full stock option benefit until the year of sale. ${ }^{78}$

In the case of the in-the-money option award, the individual cannot defer the income inclusion beyond the time the options are exercised. At exercise, the individual must report the full income benefit of $\$ 255,600$ and pay tax amounting to $\$ 74,124$. Since the stock has not been sold at this time, the executive must pay this much larger tax liability from other income sources. But when the shares are ultimately sold, the individual pays only the tax owing on the capital gain.

\footnotetext{
${ }^{75}$ See I.T.A., s. $110(1)(\mathrm{d})$.

${ }^{76}$ See id.

77 See id.

${ }^{78}$ See I.T.A., s. 7(1.1).
} 
Table 3: Summary of Tax Implications from Example 4: Sale More Than One Year After Exercise

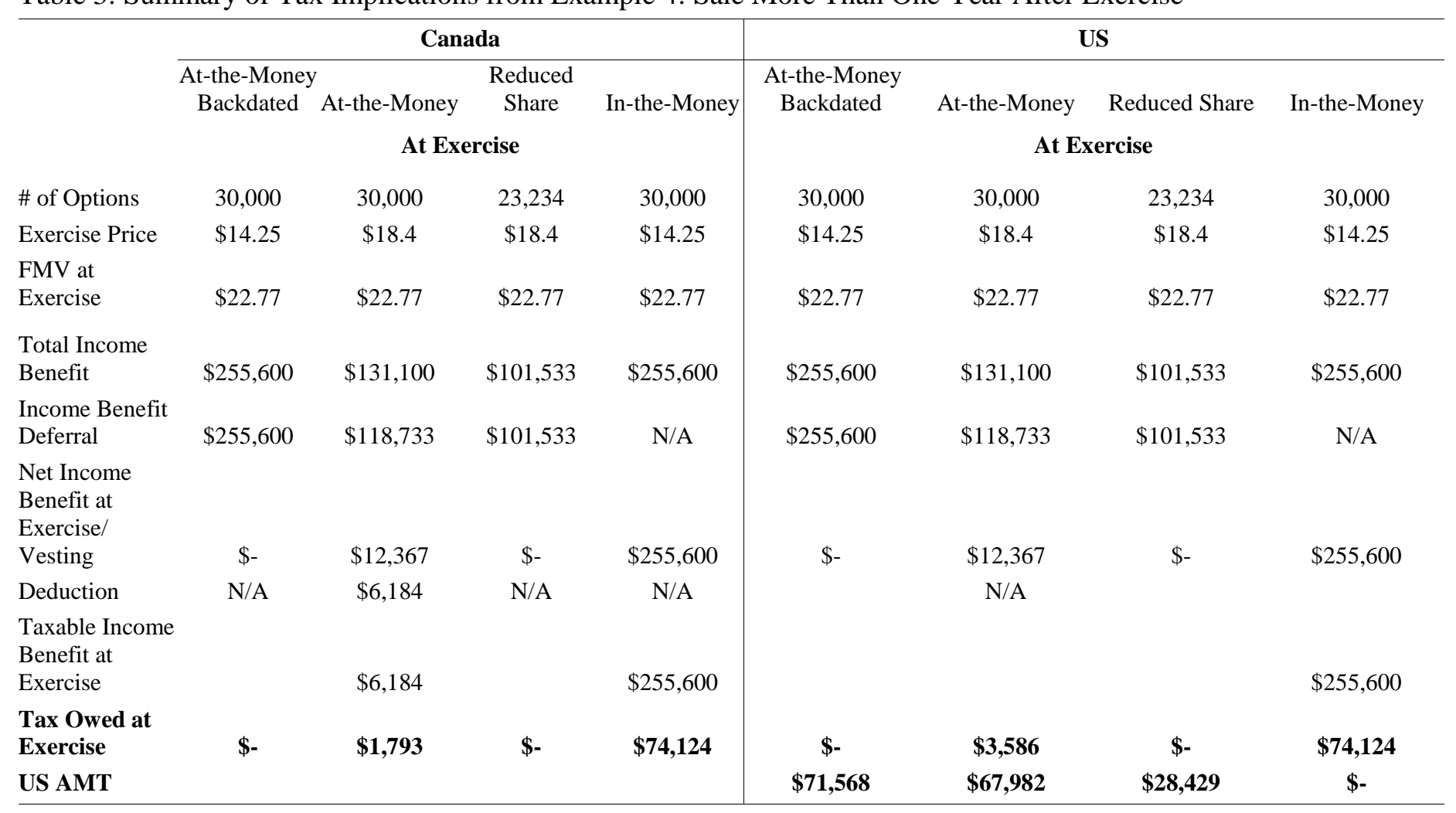




\begin{tabular}{|c|c|c|c|c|c|c|c|c|}
\hline \multirow[b]{2}{*}{ Sale Price } & \multicolumn{4}{|c|}{ At Sale } & \multicolumn{4}{|c|}{ At Sale } \\
\hline & $\$ 25$ & $\$ 25$ & $\$ 25$ & $\$ 25$ & $\$ 25$ & $\$ 25$ & $\$ 25$ & $\$ 25$ \\
\hline Gain on Shares & $\$ 66,900$ & $\$ 66,900$ & $\$ 51,812$ & $\$ 66,900$ & $\$ 322,500$ & $\$ 185,633$ & $\$ 153,344$ & $\$ 66,900$ \\
\hline $\begin{array}{l}\text { Taxable Gain } \\
\text { on Shares }\end{array}$ & $\$ 33,450$ & $\$ 33,450$ & $\$ 25,906$ & $\$ 33,450$ & $\$ 322,500$ & $\$ 185,633$ & $\$ 153,344$ & $\$ 66,900$ \\
\hline $\begin{array}{l}\text { Tax Owing on } \\
\text { Gain }\end{array}$ & $\$ 9,700.50$ & $\$ 9,701$ & $\$ 7,513$ & $\$ 9,701$ & $\$ 48,375$ & $\$ 27,845$ & $\$ 23,002$ & $\$ 10,035$ \\
\hline $\begin{array}{l}\text { Deferred } \\
\text { Income }\end{array}$ & $\$ 255,600$ & $\$ 118,733$ & $\$ 101,533$ & N/A & N/A & N/A & N/A & N/A \\
\hline Deduction & $\$ 127,800$ & $\$ 59,366$ & $\$ 50,766$ & N/A & N/A & N/A & N/A & N/A \\
\hline $\begin{array}{l}\text { Taxable Income } \\
\text { Benefit at Sale }\end{array}$ & $\$ 127,800$ & $\$ 59,366$ & $\$ 50,766$ & N/A & N/A & N/A & N/A & N/A \\
\hline $\begin{array}{l}\text { Tax Owing on } \\
\text { Income Benefit }\end{array}$ & $\$ 37,062$ & $\$ 17,216$ & $\$ 14,722$ & N/A & N/A & N/A & N/A & N/A \\
\hline $\begin{array}{l}\text { AMT credit (if } \\
\text { any) }\end{array}$ & & & & & $\$ 38,340$ & $\$ 17,810$ & $\$ 8,495$ & \\
\hline $\begin{array}{l}\text { Tax Owed at } \\
\text { Sale }\end{array}$ & $\$ 46,763$ & $\$ 26,917$ & $\$ 22,235$ & $\$ 9,701$ & $\$ 10,035$ & $\$ 10,035$ & $\$ 14,507$ & $\$ 10,035$ \\
\hline Total Tax Paid & $\$ 46,763$ & $\$ 28,710$ & $\$ 22,235$ & $\$ 83,825$ & $\$ 81,603$ & $\$ 81,603$ & $\$ 42,936$ & $\$ 84,159$ \\
\hline $\begin{array}{l}\text { Total Net } \\
\text { Employee } \\
\text { Benefit }\end{array}$ & $\$ 275,738$ & $\$ 169,290$ & $\$ 131,109$ & $\$ 238,676$ & $\$ 240,897$ & $\$ 116,397$ & $\$ 110,409$ & $\$ 238,341$ \\
\hline
\end{tabular}


A backdated option does not qualify for the deferral. If an executive reports a backdated option as an at-the-money award, exercises and sells it in different years, and does not report the stock option benefit in the exercise year (i.e., the executive claims the deferral), then the individual is underpaying taxes in the exercise year by $\$ 74,124$. In addition, in the sale year when the stock option benefit is recognized, the executive is also improperly reporting the deduction under paragraph 110(1)(d). Thus, employees who receive backdated stock options may be reassessed not only to deny any deduction claimed under paragraph 110(1)(d), but also to include the full stock option benefit in an earlier year than that in which the employee reported the benefit for tax purposes. Such reassessment would also include interest, compounded daily at a relatively high rate. Furthermore, if the executive knew of the backdating, he or she may be subject to gross negligence penalties and could even be charged with tax evasion. ${ }^{79}$

In the United States, the significant difference between this example and Example 3 is that, in this case, the options meet the holding period requirement for ISO treatment. ${ }^{80}$ Recall that the first scenario involves backdated options with an exercise price of $\$ 14.25$, purportedly the fair market value of the shares at the time of grant. In that scenario, not only is there no stock option benefit in the year of exercise, but also the entire gain (the difference between the ultimate sale price of $\$ 25$ per share and the strike price of $\$ 14.25$ per share) is a long-term capital gain and is subject to tax at the preferential rate of fifteen percent. ${ }^{81}$ Thus, the only tax obligation faced by the individual in the absence of AMT, discussed below, is tax of $\$ 48,375$ in the year of sale, leaving an after-tax benefit to the employee of $\$ 274,125$, only marginally less than the after-tax benefit in Canada.

The deferral of the benefit from the year the options are exercised is a tax preference for AMT purposes. ${ }^{82}$ For the purposes of computing the U.S. executive's AMT liability, the amount of the stock option benefit in the year the option is exercised, $\$ 255,600(30,000 \times[\$ 22.77-$ $\$ 14.25]$ ), is included in the computation of alternative minimum taxable income ("AMTI"). The impact of the AMT is that the U.S. executive's tax liability is essentially accelerated to the year the option is exercised and is subject to AMT at a relatively high rate (26-28\%, depending on the amount of AMTI). ${ }^{83}$ For illustration purposes in Table 3, we have assumed that the executive's compensation in addition to the stock option benefit is high enough both to make the AMT rate associated with the stock option benefit twenty-eight percent and to eliminate the benefit of the exemption amount for AMT purposes. ${ }^{84}$ Thus, the tentative minimum tax associated with the deferral would be $\$ 71,568$ (twenty-eight percent of $\$ 255,600$ ) although the AMT payable would likely be somewhat less. ${ }^{85}$ As a consequence, the tax payable by the employee in the year of

${ }^{79}$ See supra note 62.

${ }^{80}$ See I.R.C. $\$ \S 421(a), 422(b)$ (2006).

${ }^{81}$ See I.R.C. $§ 1(\mathrm{~h})(2006)$.

${ }^{82}$ See supra note 39. See also I.R.C. § 56(b)(3) (2006).

${ }^{83}$ See I.R.C. $\$ 55($ b) (West 2011).

${ }^{84}$ See I.R.C. $§ 55(d)$ (West 2011). Assuming that the individual is married and files a joint return, the AMTI must be at least $\$ 330,000$ to eliminate the exemption amount.

${ }^{85}$ In our example, if the executive's effective marginal tax rate of twenty-nine percent applies to a sufficient portion of the taxpayer's income (for regular income tax purposes), then the AMT payable would be approximately one percent less than $\$ 71,568$ (and, as the income subject to a marginal tax rate exceeding twenty-eight percent increases, the amount of AMT decreases). Because of the various factors that can affect AMT, we have assumed for illustration purposes in Table 3 that AMT is equal to the tentative minimum tax payable. See supra note 39. 
exercise is dramatically higher in the United States than in Canada - and will have to be paid from other sources of income if the employee wishes to avoid selling any shares acquired in that year. The amount of AMT can be carried forward and applied as a credit in subsequent years to the extent that the executive's regular tax liability in that year exceeds the tentative minimum tax for that year. ${ }^{86}$ Assuming there is significant income taxed at the highest marginal rate (assumed to be twenty-nine percent), there would be a tax saving each year (i.e., at least the one-percent difference between the AMT rate and the regular tax rate). In the year the shares are sold, the AMT liability is computed on the assumption that the cost base of the shares for AMT purposes is \$22.77 rather than the $\$ 14.25$ cost assumed for regular tax purposes. However, because the long-term capital gains tax rate of fifteen percent is applicable for both AMT and regular tax purposes, the AMT credit available that year will, in effect, be limited to fifteen percent of the benefit included in income in the year of exercise rather than the full AMT paid that year. ${ }^{87}$ Thus, the AMT liability in the year of exercise may act as more than an anti-deferral mechanism; it acts as a real cost in this case to the extent that the credit cannot be fully utilized by the time the shares are sold. As indicated in Table 3, the Canadian executive enjoys a net employee benefit of almost $\$ 35,000$, or $14.5 \%$ more than the U.S. executive. ${ }^{88}$

In the second scenario in the United States, only 5,434 options per year of vesting qualify for ISO treatment. ${ }^{89}$ Since this is less than the 6,000 options that vest each year under this plan, the excess options (566 per year) are treated as NSOs, with the stock option benefit on these options subject to tax in the year of exercise. ${ }^{90}$ Consequently, in the year of exercise, the stock option benefit on 27,170 exercised options will be deferred until the year in which the shares are sold for regular income tax purposes, with the balance ${ }^{91}$ subject to tax in the year of exercise. ${ }^{92}$ Subject to AMT, the result is similar to that in Canada, except that there is no equivalent to the deduction under paragraph 110(1)(d) of the I.T.A., so that the entire $\$ 12,367.10$ is subject to tax in the year of exercise at the employee's marginal tax rate. ${ }^{93}$ For AMT purposes, however, the entire stock option benefit (including the 5,434 options that qualify for ISO treatment) is included in income in

${ }^{86}$ See I.R.C. § 53(b) (2006).

${ }^{87}$ See I.R.C. $§ 55($ b) (West 2011). Assuming that the executive's compensation in addition to the stock option benefit is high enough to make the AMT rate twenty-eight percent (on income other than the long-term capital gain) and to eliminate the benefit of the exemption amount, the AMT payable on the long-term capital gain will be $\$ 10,035[15 \%$ $\times 30,000 \times(\$ 25-\$ 22.77)]$ compared to the regular tax of $\$ 48,375$, so that $\$ 38,340$ of the AMT credit carried over from the year of exercise could be applied to the extent that it has not been previously used. In other words, approximately $53.5 \%$ (far less than all) of the AMT credit carried over from the year the options were exercised could be applied in the year of sale to reduce the regular tax otherwise owing that year. See I.R.C. $§ 55$ (West 2011); I.R.C. § 56 (2006).

${ }^{88}$ See supra Table 3.

${ }^{89}$ See I.R.C. $\$ \S 421(a), 422(a)-(b)$ (2006).

${ }^{90}$ See I.R.C. $\$ 83$ (2006).

${ }^{91}$ In this scenario, the benefit on 2,830 options.

${ }^{92}$ See I.R.C. $\$ \S 421(\mathrm{a}), 422(\mathrm{~d})(2006)$.

${ }^{93}$ Id.; see also I.R.C. § 55(b) (West 2011); I.R.C. § 56(b)(3) (2006). 
the year of exercise, dramatically increasing the tax liability in that year. ${ }^{94}$ Thus, for AMT purposes, the tentative minimum tax payable would be the same as in the first scenario. ${ }^{95}$

In the year of sale in the second scenario, the deferred stock option benefit will form part of the long-term capital gain realized by the employee, so that for regular income tax purposes the employee benefits not only from a deferral of this income inclusion, but also from the application of the long-term capital gains tax rate of fifteen percent. ${ }^{96}$ The $\$ 185,632.90$ long-term capital gain in the year of sale is made up of $\$ 179,322^{97}$ plus $\$ 6,310.90 .^{98}$ This amount is subject to tax at the rate of fifteen percent, for a tax liability of $\$ 27,845$. ${ }^{99}$ As in the first scenario, the AMT liability in the year the shares are sold is computed on the assumption that the cost base of the shares for AMT purposes is $\$ 22.77$ rather than the $\$ 14.25$ cost assumed for regular tax purposes. ${ }^{100}$ Assuming that the executive's compensation in addition to the stock option benefit is high enough for an AMT rate of twenty-eight percent to apply on income other than the long-term capital gain, and is high enough for the benefit of the exemption amount to be eliminated, the AMT payable on the longterm capital gain will be $\$ 10,035,{ }^{101}$ compared to the regular tax of $\$ 27,845$. Therefore, $\$ 17,810$ of the AMT credit carried over from the year of exercise could be applied to the extent that it has not been previously used. ${ }^{102}$ Due to the significant AMT liability in the year of exercise, which is only partially creditable in the year of sale, the U.S. executive is in a substantially worse position than the Canadian executive. ${ }^{103}$

Under the reduced share option scenario in the United States, the regular income tax treatment in the year of exercise is similar to that in the first scenario, with the individual deferring the full stock option benefit until the year of sale. However, for AMT purposes, the entire stock option benefit is included in AMTI. ${ }^{104}$ Based on the same assumptions as in the preceding scenarios, the AMT liability would be $\$ 28,429$ in the year of exercise. ${ }^{105}$ In the year of sale, the regular tax liability would be $\$ 23,002$ compared to an AMT liability of $\$ 14,507$, so that an AMT credit of $\$ 8,495$ could be applied to reduce the tax liability to $\$ 14,507 .{ }^{106}$ Again, the resulting after-tax benefit to the employee is significantly less than that in Canada. ${ }^{107}$

${ }^{94}$ See supra note 39 and accompanying text

95 See supra note 39 and accompanying text (the AMT payable will be somewhat less than the tentative minimum tax payable); see also supra Table 3 (for illustrative purposes, the AMT is assumed to be the difference between $\$ 71,568$ tentative minimum tax payable and the $\$ 3,586$ regular tax payable on the 2,830 options).

${ }^{96}$ See I.R.C. § 1(h) (2006).

${ }^{97}$ The gain realized on the $27,170(5 \times 5,434)$ ISOs, calculated as $[27,170 \times(\$ 25-\$ 18.40)]$. See I.R.C. $\S 421$ (a) (2006).

(2006)

${ }^{98}$ The gain realized on the $2,830(5 \times 566)$ NSOs, calculated as $[2,830 \times(\$ 25-\$ 22.77)]$. See I.R.C. $\S 83(a)$

${ }^{99}$ See I.R.C. $§ 1(\mathrm{~h})(2006)$.

${ }^{100}$ See I.R.C. $\$ 56(\mathrm{~b})(3)(2006)$.

${ }^{101} 15 \% \times 30,000 \times(\$ 25-\$ 22.77)=\$ 10,035$. See I.R.C. $\$ \S 55(b),(d)($ West 2011).

${ }^{102}$ See I.R.C. § 53(a) (2006).

${ }^{103}$ See supra Table 3 (the Canadian executive enjoys a net employee benefit of almost $\$ 53,000$, or $45.4 \%$ more than the American executive in this scenario).

${ }^{104}$ I.R.C. § 56(b)(3) (2006).

${ }^{105}$ See supra pp. 158-59 (discussing the assumptions behind the preceding examples).

${ }^{106}$ See supra Table 3.

${ }^{107}$ The Canadian executive realizes $\$ 20,700$ after tax, or $18.75 \%$ more than the U.S. executive. See id. 
Finally, the in-the-money option scenario does not benefit from ISO treatment, so the entire stock option benefit is subject to tax in the year of exercise at the employee's marginal tax rate (and therefore no AMT will be payable). ${ }^{108}$ However, the gain realized on the ultimate sale of the shares is a long-term capital gain that is taxed at the fifteen percent preferential rate. ${ }^{109}$ The after-tax benefit to the U.S. employee in this one scenario is only marginally less than that in Canada. ${ }^{110}$

The fourth example demonstrates that the potential impact of the AMT can more than offset the preference for ISOs in the United States so that only in relatively few circumstances ${ }^{111}$ is an American executive in a similar (or perhaps better) position than a Canadian executive. This example also highlights another phenomenon, not explored in this paper, of "exercise backdating." 112 For U.S. executives, exercise backdating could mean the difference between ISO treatment and NSO treatment (but in the year the stock was sold, as it would be a disqualified disposition of ISOs) for up to $\$ 100,000$ worth of options per vesting year. ${ }^{113}$ For Canadian executives, exercise backdating is unlikely to occur because there is no holding period requirement in Canada in order to benefit from the preferential treatment in paragraph $110(1)(\mathrm{d}){ }^{114}$ In fact, exercise backdating would only result in an increased after-tax benefit when the employee is not entitled to a deduction under paragraph $110(1)(d) .{ }^{115}$ Exercise backdating is thus likely a phenomenon limited to the United States.

\section{CONCLUSION}

The goal of this paper was to highlight the significant effect of personal income taxes on the after-tax returns to backdated options held by Canadian executives relative to U.S. executives. Indeed, as the examples in the previous section indicate, Canadian executives by and large are financially better off than their U.S. counterparts from employee stock options in all cases. ${ }^{116}$ This holds true even for options that benefit from ISO treatment in the United States, due to the

${ }^{108}$ See I.R.C. $\$ \S 83,421(a), 422(b)(2006)$.

${ }^{109}$ See I.R.C. $\$ 1(\mathrm{~h})(1)(\mathrm{C})(2006)$.

${ }^{110}$ See Emmanuel Saez \& Michael Veall, The Evolution of High Incomes in Northern America: Lessons from Canadian Evidence, 95 AM. ECON. REv. 831, 837, 845 (2005) (in fact, the after-tax benefit in this scenario could be higher in the United States than in Canada because the marginal tax rate faced by most executives in Canada is significantly higher than twenty-nine percent so that even though only one-half of the stock option benefit and one-half of the capital gain are included in income, the effective rate of tax on the benefit would likely exceed fifteen percent).

${ }^{111}$ In the case of in-the-money options (the fourth scenario) as well as in situations where the executive has a sufficiently large amount of non-stock option income to eliminate or minimize the impact of AMT.

${ }^{112}$ Dan Dhaliwal et al., Taxes and the Backdating of Stock Option Exercise Dates, 47 J. AccT. \& Econ. 27, 2729 (2009) (describing "exercise backdating" as the practice of reporting the exercise of stock options at an earlier time, and perhaps lower price, than the actual exercise date of the options).

${ }^{113}$ See I.R.C. $\$ \S 83(\mathrm{a}), 421(\mathrm{a}), 422$ (2006).

${ }^{114}$ See I.T.A., s. $110(1)(\mathrm{d})$.

${ }^{115}$ In the case of in-the-money options (as distinct from backdated at-the-money options), which are almost never purposefully granted to Canadian executives in any event due to stock exchange restrictions. See supra note 5.

${ }^{116}$ See supra Part III (as illustrated in examples). 
application of AMT. ${ }^{117}$ This analysis also shows that personal income tax may have played a role in executives' willingness to accept backdated options in Canada but not in the United States. ${ }^{118}$

Our results raise an important policy question as to why executive stock options are treated in Canada essentially as an investment rather than as compensation, ${ }^{119}$ even when the options are exercised and sold at the same time. Perhaps it is time for Canada to rethink this deduction, either to eliminate it completely or to attach a holding period requirement similar to that in the United States. $^{120}$

Finally, the discussion above indicates that there is a need to empirically investigate the incidence of backdating among Canadian companies. No comprehensive study has been done on the extent to which backdating exists in Canada, as has been done in the United States. Is backdating a widespread problem in Canadian financial markets or is it limited to only a handful of companies? Similarly, no comprehensive study has been done to determine if backdated stock options have been supplanted by an alternative incentive award, such as restricted stock units (whether manipulated or not) or another nefarious pricing behavior such as the opportunistic timing of stock option repricing. ${ }^{121}$ This investigation is necessary to inform policymakers of whether their existing efforts to combat option backdating have been successful, and whether they need to shift gears toward targeting more contemporary forms of fraudulent compensation practice. With respect to tax policy, another angle worth considering is how various changes to the Canadian I.T.A. may have impacted the extent of backdating. ${ }^{122}$ Finally, investigating backdating in Canada will provide results that will be useful not only for those in Canada, but also to inform those interested in examining backdating in the United States.

${ }^{117}$ See I.R.C. $\$ 55$ (West 2011).

${ }^{118}$ See generally Ryan A. Compton et al., Backdating, Tax Evasion, and the Unintended Consequences of Canadian Tax Reform, 59 TAX NOTES INT'L 671 (2010) (discussing the link between Canadian tax reform and stock option backdating).

${ }^{119}$ See I.T.A., s. $110(1)(\mathrm{d})$.

${ }^{120}$ See Sandler, supra note 24, at 270-71 (suggesting such a rethinking back in 2001). See also LIBERAL PARTY OF CANADA, Your FAMILY. Your FutURE. Your CANADA. 1, 11 (2011), available at

http://cdn.liberal.ca/files/2011/04/liberal_platform.pdf (in the run-up to the 2011 federal election, the Liberal Party of Canada, promised to limit the deduction to $\$ 50,000$ annually by arguing that "[c]urrently, 8,000 Canadians who earn more than $\$ 500,000$ a year deduct an average of $\$ 400,000$ from their taxable income based on stock options. Many other taxpayers are claiming much more modest amounts. But those 8,000 high earners are receiving three-quarters of the total claimed under the stock option deduction ... . The change will . . return approximately $\$ 600$ million to the public purse over two years.").

${ }^{121}$ Such pricing behavior could take place as a result of responses by policymakers in Canada and the United States to concerns about backdated stock options.

${ }^{122}$ For example, there may be increased evidence of backdating following the introduction in 1984 of paragraph 110(1)(d) or the extension of the deferral of the stock option benefit in 2000 to public company employees. 


\section{APPENDIX}

A key driver behind this paper is to isolate the role taxes may play in the returns from backdating and their influence on the decision by an executive to accept a backdated stock option in lieu of some other form of compensation (options or otherwise) as well as her decision to report a backdated option for tax purposes. To further clarify beyond the main text, consider the factors that determine the monetary return from a stock option for a single share that has been exercised and then subsequently sold $(V)$ at the same time or later in the same tax year: ${ }^{123}$

$$
V=\left(P_{E}-P_{x}\right)\left(1-\tau_{\mathrm{y}}\right)+\left(P_{S}-P_{E}\right)\left(1-\tau_{\mathrm{g}}\right)
$$

where $P_{E}$ represents the price of the underlying share at option exercise, $P_{X}$ is the option exercise price, $\tau_{y}$ is the tax rate on the income benefit associated with the option exercise, $P_{S}$ is the price of the stock once finally sold, and $\tau_{\mathrm{g}}$ is the tax on any gains arising over the period the share was acquired and then eventually sold.

Equation (1) is essentially composed of two parts: (a) the income benefit accrued when the option is exercised (assuming that the exercise price is less than the existing market price), which is taxed at rate $\tau_{y}$; and (b) the capital gain realized from the time the options are exercised to the time the acquired stock is sold, which is taxed at rate $\tau_{\mathrm{g}}$. In the case where the option is exercised and sold on the same day, the gain is zero since $P_{S}=P_{E}$.

$P_{X}$ represents the exercise price associated with a given executive stock option. However, in the context of backdating, it is important to deconstruct $P_{X}$ into two components: (a) the true price of the underlying stock at the time the executive stock option is granted $\left(P_{T}\right)$; and (b) the discount due to backdating $(\delta)$.

$$
P_{X}=P_{T}-\delta
$$

This allows us to see clearly that in the case of no backdating, $\delta=0$ and therefore $P_{X}=P_{T}$; the exercise price associated with the grant is equal to the true price of the underlying share at the time the options were granted. This is referred to as a "currently priced option." In the case of $\delta>$ 0 , the exercise price for the grant is lower than the actual share price at the time of the grant because $P_{X}<P_{T}$. If it is claimed that the option was granted when the price was trading at $P_{X}$, then we have a "backdated option." To account for this information, we can restate equation (1) as follows:

$$
V=\left(P_{E}-P_{T}+\delta\right)\left(1-\tau_{\mathrm{y}}\right)+\left(P_{S}-P_{E}\right)\left(1-\tau_{\mathrm{g}}\right)
$$

Our interest lies in demonstrating three factors that affect the returns from a stock option (once it is exercised and the underlying stock is then sold): $\tau_{y}, \tau_{\mathrm{g}}$, and $\delta$. Taking the derivative of (3) with respect to these three variables in turn yields the following:

\footnotetext{
${ }^{123}$ This restriction eliminates the possibility of ISOs. The focus of this article is to understand the influence of taxes on backdating in Canada, and Canada does not have the equivalent of an ISO.
} 


$$
\begin{gathered}
\frac{\partial V}{\partial \delta}=\left(1-\tau_{\mathrm{y}}\right)>0 \\
\frac{\partial V}{\partial \tau_{g}}=-\left(P_{S}-P_{E}\right)<0 \\
\frac{\partial V}{\partial \tau_{y}}=-\left(P_{E}-P_{T}+\delta\right)<0
\end{gathered}
$$

Equation (4) demonstrates that, assuming $\tau_{y}<1$ (i.e., the tax rate is less than one hundred percent), returns increase the larger the discount of the exercise price relative to the actual trading price on the day the option was granted (i.e., the more the option exercise price was backdated). This of course is the general principle behind backdating: lower the exercise price relative to the trading price at the time of grant to gain a higher return, and so this positive relationship between $\delta$ and $V$ is fully expected. It shows that a backdated option will be preferred to a currently dated option.

Our focus, however, lies on the role taxes may play in determining the demand for a backdated option. There are two tax rates to consider: first, the tax related to the gain, and second, the tax related to the income benefit. In Equation (5) we see a negative relationship between tax $\left(\tau_{\mathrm{g}}\right)$ and returns to the executive, where $\tau_{\mathrm{g}}$ represents the tax on capital gains accruing after exercising the option and holding the stock until sale. It is evident that this portion of the return is unrelated to the backdating discount, and so requires no further elaboration in the context of backdating.

Equation (6) is the equation of most interest in terms of the potential relationship between tax and the benefit from backdating. Equation (6) demonstrates that a negative relationship exists between $\tau_{y}$ and $V$; the lower the tax on income received through exercising an option grant, the higher the return. As discussed in the main text, however, in Canada different effective tax rates apply to the income benefit based on the reported presence of $\delta$, whereas in the United States the same tax rate applies regardless. The effective rate of taxation with respect to the income benefit from stock options is higher in the United States than in Canada, as Canadians can claim a deduction equal to fifty percent of the income inclusion. But this reduced rate only applies if $\delta=0$, or the option is reported as such. ${ }^{124}$ That is, Equation (3) applies to the pre-I.R.C. $\S 409 \mathrm{~A}$ environment in the United States whereas the situation in Canada is better represented as follows:

$$
V=\mathrm{I}[\delta \leq 0]\left(P_{E}-P_{T}+\delta\right)\left(1-\tau_{y 0}\right)+\mathrm{I}[\delta>0]\left(P_{E}-P_{T}+\delta\right)\left(1-\tau_{y 1}\right)+\left(P_{S}-P_{E}\right)\left(1-\tau_{\mathrm{g}}\right)
$$

where I[· $]$ is an indicator function that takes the value of one when the statement in the square brackets is true and zero when it is false. The relevant part of the value of the income benefit is then triggered by the indicator function for whether the option is discounted or not, as this can result in tax differences $\left(\tau_{y 0}\right.$ vs. $\left.\tau_{y l}\right)$ which can provide the tax incentive for an individual who receives a backdated option in Canada to report it as though it were not.

\footnotetext{
${ }^{124}$ See I.T.A., s. 7, 110(1)(d).
} 
It follows that the Canadian regime, where $\tau_{y 0}<\tau_{y l}$, rewards backdating ${ }^{125}$-or, more correctly, rewards backdating if the strike price reported for tax purpose is $P_{X}$ and not $P_{T}$. In terms of the decision to accept a backdated versus an in-the-money option, until recently in the United States an executive would be indifferent between the two options ${ }^{126}$ whereas a Canadian executive would not be indifferent. ${ }^{127}$ As a result of the lower tax rate in Canada on the income benefit of the option, a Canadian executive is able to "capture" a greater amount of the backdated return than the U.S. executive.

\footnotetext{
${ }^{125}$ The executive earns a higher after-tax return from a misreported backdated option in Canada than in the United States.

${ }^{126}$ The tax rate on the two would be identical.

${ }^{127}$ Canadian executives would prefer a misreported backdated option with the available income tax deduction, effectively lowering their tax rate, which is not available for an in-the-money option.
} 